\title{
Structure and tectonics of the continental margins of India and the adjacent deep ocean basins: current status of knowledge and some unresolved problems
}

\author{
CSIR - National Institute of Oceanography, Dona Paula, Goa 403 004, India
}

(Received : 24/01/2019; Revised accepted : 18/03/2019)

https://doi.org/10.18814/epiiugs/2020/020039

The Indian Ocean and the bordering continental margins are characterized by a number of tectonic features consisting of deep ocean basins, aseismic ridges/ submarine plateaus and seamounts. Marine geophysical studies carried out over these regions for the past four decades have led to an increased understanding of the formation and evolution of these features. The present paper synthesizes an up-to-date compilation of the results of the salient inferences of those studies to describe the structure and tectonic evolution of these features as well as the Indian Ocean in general. A review of the existing knowledge on the structure and tectonics of the continental margins of India and the adjacent ocean basins reveal the existence of several unresolved problems, primarily due to the inherent tectonic complexities or the paucity of adequate data. Some of the major problems that need to be addressed/examined are: the existence and extent of the Prathap and Kori-Comorin ridges; the locations of the continent-ocean boundaries around the continental margins of India; the timing of formation of the deep offshore regions adjacent to the Indian continental margins; the deeper crustal structure and trend of the $85^{\circ} \mathrm{E}$ Ridge; the crustal configuration as well as the extent of the postulated micro-continental slivers; and the cause of intense seismicity over the Chagos Bank segment of the Laccadive-Chagos Ridge. In addition to addressing these questions, the present paper suggests ways to go forward by acquiring high-resolution and deep penetration multichannel seismic reflection data, seismic refraction data using Ocean Bottom Seismometers (OBS) and closely spaced sea-surface and deep-tow magnetic profiles along with high-resolution seafloor mapping.

\section{Introduction}

The present day configuration of the continents and the deep ocean basins of the Indian Ocean (Figure 1) resulted from the fragmentation and dispersal of the eastern sector of the Gondwanaland since the Late Jurassic. In this framework, the Indian Ocean was formed by rifting and subsequent drifting among Africa, Antarctica, Australia, India, Madagascar and Seychelles. The deeper basins of the Indian Ocean bear the imprints of this plate tectonic history, superposed over time by several other tectonic events such as the Kerguelen, Marion and Rèunion hotspots volcanism, the IndiaEurasia collision and the deformation of the Central Indian and Wharton basins. A detailed understanding of the evolution of all these resultant features is important to trace the plate kinematic history of the Indian Ocean and the bordering continental margins.

Geophysical investigations carried out in the Indian Ocean and the adjacent continental margins for the past four-odd decades have built a significant knowledge-base on the structure and tectonics of the different sectors of the Indian Ocean. However, partly due to the inherent tectonic complexities of the region and partly on account of the paucity of adequate data, several questions which have a strong bearing on the plate tectonic evolutionary history of the Indian Ocean still persist. This paper is an attempt to highlight some of the more important unresolved questions against the backdrop of our current status of knowledge on the structure and tectonics of the Indian Ocean region with emphasis on the continental margins of India and the adjacent deep ocean basins.

\section{Tectonic framework - current status of knowledge}

\section{Continental margins of India}

The continental margin of India is subdivided into western and eastern continental margins. Both these are passive margins formed during different episodes of breakup and dispersal of the East Gondwanaland. 

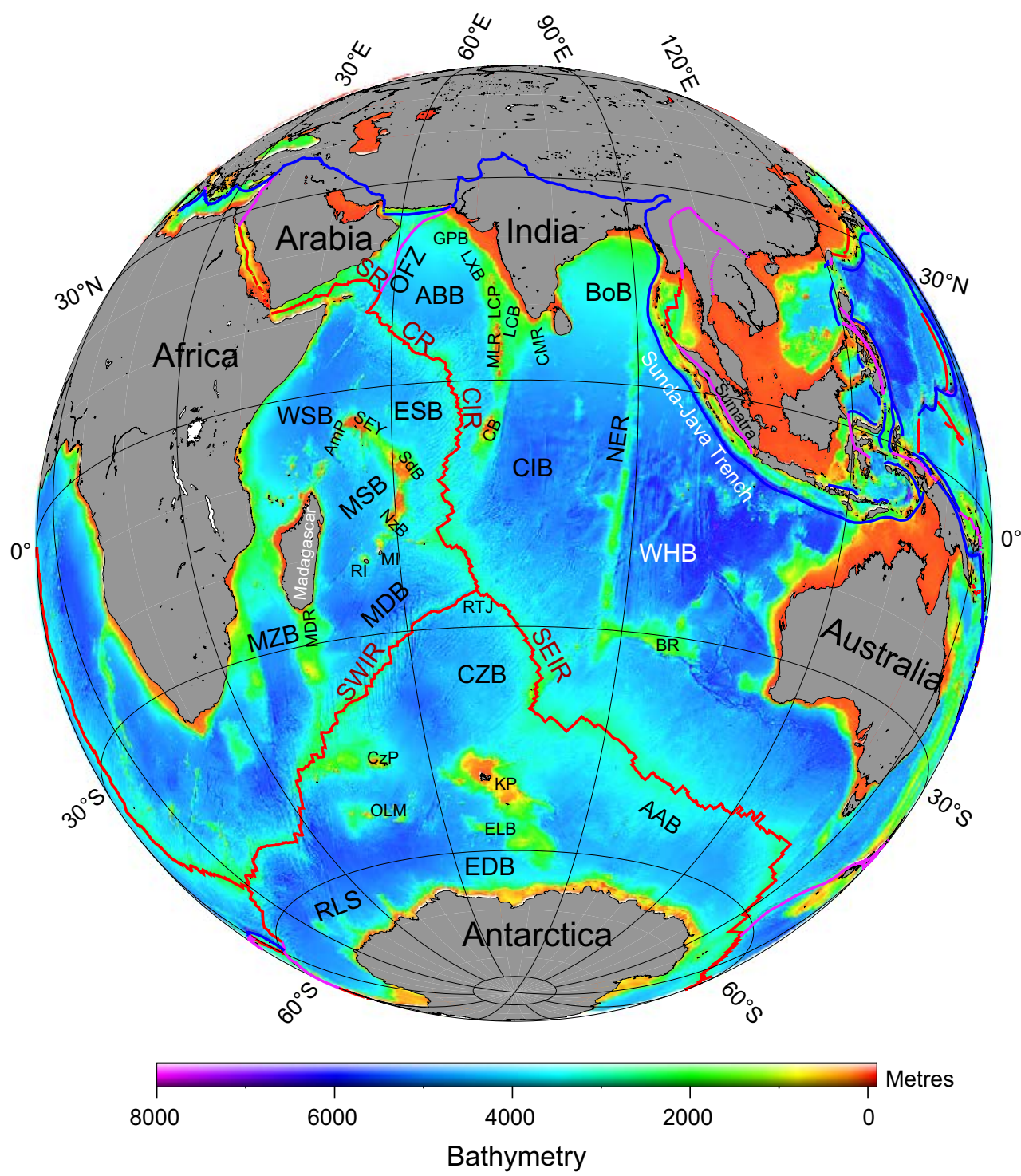

Figure 1. Map of the Indian Ocean showing the various major seafloor features as depicted by the satellite-derived topography (Smith and Sandwell, 1997; Smith and Sandwell, 2014). The thick lines with red, blue and pink colours represent divergent, convergent and transform plate boundaries. ABB: Arabian Basin; ESB: Eastern Somali Basin; GPB: Gop Basin; LXB: Laxmi Basin; LCB: Laccadive Basin; BoB: Bay of Bengal; CIB: Central Indian Basin; CZB: Crozet Basin; MDB: Madagascar Basin; MSB: Mascarene Basin; WSB: Western Somali Basin; MZB: Mozambique Basin; RLS: Riiser-Larsen Sea; EDB: Enderby Basin; WHB: Wharton Basin; AAB: AustralianAntarctic Basin; OFZ: Owen Fracture Zone; SR: Sheba Ridge; CR: Carlsberg Ridge; CIR: Central Indian Ridge; SEIR: Southeast Indian Ridge; SWIR: Southwest Indian Ridge; LCP: Laccadive Plateau; MLR: Maldive Ridge; CB: Chagos Bank; CMR: Comorin Ridge; SEY: Seychelles Bank; SdB: Saya de Malha Bank; NzB: Nazareth Bank; MI: Mauritius Island; RI: Rèunion Island; MDR: Madagascar Ridge; CzP: Crozet Plateau; OLM: Ob-Lena-Marion Dufresne Seamount Chain; KP: Kerguelen Plateau; ELB: Elan Bank; BR: Broken Ridge; RTJ: Rodriguez Triple Junction.

sedimentary sub-basins delimited by transverse basement arches or faultbounded highs characterise the shelf (Figure 2; Ramaswamy and Rao, 1980; Biswas and Singh, 1988; Biswas, 1989; Singh and Lal, 1993). From north to south, these are the Kutch Basin, Saurashtra Basin, Mumbai Basin, Konkan Basin and the Kerala Basin, delimited by the nearly E-W trending Saurashtra Arch, Son-Narmada Lineament, Vengurla Arch and the Tellicherry Arch, respectively (Sriram et al., 2006; Bastia and Radhakrishna, 2012). The Kutch Basin forms the northwestern part of the western continental margin, between Nagar-Parkar Ridge in the north and the ENE Saurashtra Arch to the south (Biswas, 1982, 1987; Sriram et al., 2006; Bisen et al., 2010). These basement features cut across several coast-parallel horst-graben structures in the continental shelf. The Saurashtra Basin is located between the Kutch Basin in the north and the Mumbai Basin in the south. The basement trends in this basin are nearly E-W, as evidenced by the continuation of Narmada and Kutch rifts and the Saurashtra Arch onto the continental shelf (Biswas, 1982; Bhattacharya and Subrahmanyam, 1986). The Mumbai Basin, located between the Saurashtra Basin and the Konkan Basin, is bounded to the north by the offshore extension of the NarmadaSon lineament and to the south by the Vengurla Arch. The continental shelf in this part contains a system of shelfal horst-graben complex, parallel to the NNW-SSE trending Dharwar trend (Biswas, 1989; Gombos et al., 1995). The main structural elements that constitute the Mumbai Basin are the Surat Depression, Murud Depression, Rajapur Depression, Bombay Platform, Heera-Bassein Block,

\section{Western continental margin of India}

The western Indian continental margin consists of (i) a wide continental shelf extending NW-SE, (ii) a remarkably straight shelf edge limited by the $200 \mathrm{~m}$ isobath and (iii) a narrow continental slope bounded by $200 \mathrm{~m}$ and $2000 \mathrm{~m}$ isobaths (Naini, 1980; Biswas, 1989). The shelf is $300 \mathrm{~km}$ wide in Kutch-Saurashtra area but gradually narrows down southward to $50 \mathrm{~km}$ off south Kerala; complementing this, the slope is narrow in the north, widening southward. Several
Ratnagiri Block and the Shelf Margin Basin, along with the N-S trending Diu Arch and the NE-SW trending Ratnagiri Arch (Mathur and Nair, 1993). The Konkan Basin is located between the Mumbai Basin in the north and the Kerala Basin in the south. The Mumbai and Konkan basins are separated by the southwesterly plunging Vengurla arch (Mathur and Nair, 1993), while the Konkan Basin and Kerala Basin are separated by the Tellicherry Arch. Subrahmanyam et al. (1995) inferred the presence of a coast-parallel horst-graben complex consisting of the inner shelf, mid-shelfal basement ridge 
and a shelf margin basin in the Konkan Basin, between $12^{\circ} 20^{\prime} \mathrm{N}$ and $15^{\circ} 00^{\prime} \mathrm{N}$. Rao et al. (2010) identified a chain of parallel, discrete margin highs existing immediately west of this shelf margin basin in the midcontinental slope region off southwest coast of India.

The Kerala Basin is the southernmost basin in the western continental margin of India, extending from the Tellicherry Arch in the north to Cape Comorin in the south (Figure 2). The entire western continental margin in the northern part shows a regular shelf-slope topography, but the mid-continental slope region south off Cochin shows an anomalous topography due to the presence of two contiguous terraces, the Alleppey Terrace and the Trivandrum Terrace (Figure 3), together known as the AlleppeyTrivandrum Terrace Complex (Yatheesh et al., 2006; Yatheesh et al., 2013b). The seafloor depth of the Alleppey Terrace varies between 300 $\mathrm{m}$ and $400 \mathrm{~m}$, while that of the Trivandrum Terrace varies between $1500 \mathrm{~m}$ and $1900 \mathrm{~m}$ (Yatheesh et al., 2013b). The southerly limit of the Alleppey Terrace is defined by an EW trending scarp face, referred to as the Quilon Escarpment. The seismic reflection data in and around this region reveals that the Alleppey Terrace is associated with a basement high in the west of its present-day geometry (Unnikrishnan et al., 2018). The Trivandrum Terrace is characterized by the presence of a NNW-SSE trending wide basement high in its central part that is flanked by thick sediment-filled grabens in its easterly and westerly sides (Figure 3b, 3c), referred to as the TT-Eastern Basin and the TT-Western Basin, respectively (Yatheesh et al., 2013b). Both these basins are characterized by the presence of NNW-SSE trending block-faulted basement features, extending across the entire Trivandrum Terrace. The western limit of the Alleppey-Trivandrum Terrace Complex is defined by a $~ 500 \mathrm{~km}$ long steep linear escarpment, known as the Chain-Kairali Escarpment. Some authors (Subrahmanyam and Chand, 2006; Nathaniel et al., 2008; Nathaniel, 2013) considered the linear gravity low associated with this feature to represent the landward extension of the Vishnu Fracture Zone. However, based on updated tectonic elements information from the conjugate continental margins and the adjacent deep offshore regions off southwest coast of India and the southeast coast of Madagascar and with the help of revised plate tectonic reconstruction of the Western Indian Ocean, Shuhail et al. (2018) demonstrated that the
Chain-Kairali Escarpment does not represent the landward extension of the Vishnu Fracture Zone.

\section{Eastern continental margin of India}

The eastern continental shelf of India (Figure 2) trends in a NESW direction towards north in the regions off West Bengal, Odisha, and Andhra Pradesh, and in an $\sim \mathrm{N}-\mathrm{S}$ direction towards south, off Tamil Nadu. Compared to the western continental margin of India, the shelf in the eastern continental margin of India is found to be irregular and narrower, with a variable width of $\sim 120 \mathrm{~km}$ around Digha, $60 \mathrm{~km}$ off north Andhra Pradesh and $\sim 35 \mathrm{~km}$ off Tamil Nadu (Faruque et al., 2014). The water depth of the shelf break varies irregularly from $\sim 220$ to $\sim 70$ meters. The maximum value of $\sim 220 \mathrm{~m}$ depth for the shelf break is observed from Gopalpur to the Chilka Lake while a minimum value of $\sim 70 \mathrm{~m}$ is observed between Karaikkal and Nagapattinam as well as between Krishna and Godavari basins 
(Murthy et al., 1993; Murthy et al., 2012). Regional geophysical investigations on the eastern continental margin of India suggest that the margin can be considered to have a northern rifted segment and a southern transform segment (Subrahmanyam et al., 1999; Chand et al., 2001). The interpretation of the transform margin for the southern segment has also been supported by Krishna et al. (2009), based on the presence of normal faults with major slips, narrow stretch of deformed crust and limited lithospheric extension. Recently, Nemcok et al. (2013) reported the presence of a proto-oceanic crust, representing a transitional zone between the extended continental crust and pure oceanic crust, all along the eastern continental margin of India using deep-penetrated multichannel seismic reflection data. Radhakrishna et al. (2012b) have provided the crustal architecture of the central part of the eastern continental margin of India, based on integrated gravity, seismic reflection and seismic refraction data. They also supported the idea of the presence of a proto-oceanic crust in this part of the continental margin.

The eastern continental margin of India consists of five major onshore-offshore sedimentary basins - the Bengal Basin, Mahanadi Basin, Krishna-Godavari Basin, Palar Basin and the Cauvery Basin (Figure 2) - separated by major tectonic elements (Lal et al., 2009; Bastia and Radhakrishna, 2012; Murthy et al., 2012). The Bengal and Mahanadi basins are separated by a major fault, while the Mahanadi, Krishna-Godavari, Palar and the Cauvery basins are separated from the adjacent basins by the Visakhapatnam, Nayudupeta and Chingleput highs respectively (Lal et al., 2009). The Bengal Basin is bordered by the Indian shield in the west, Shillong Plateau in the north, the Indo-Burma Ranges in the east and the Bay of Bengal to the south. This basin has regional tectonic trends oriented N-S, NE-SW and ENE-WSW (Khan and Chouhan, 1996). Based on the overall geologic settings, the Bengal Basin has been divided into a Stable Continental Shelf and the Bengal Foredeep, respectively to the west and east of the continental slope (also known as Hinge Zone) (Alam et al., 2003; Uddin and Lundberg, 2004; Hossain et al., 2019). The Mahanadi Basin is located between the Bengal Basin in the north and the Krishna-Godavari Basin to the south. Subrahmanyam et al. (2008) inferred the presence of a series of coast-parallel structural highs and depressions and their shearing patterns in the Mahanadi offshore, using bathymetry, magnetic and gravity data. Based on the interpretation of gravity and magnetic data and the basement configuration derived from the multichannel seismic reflection sections, several researchers (Nayak and Rao, 2002; Subrahmanyam et al., 2008; Bastia et al., 2010; Rao and Radhakrishna, 2014 etc.) have inferred the continuity of the $85^{\circ} \mathrm{E}$ Ridge into the Mahanadi Basin till the coast at Chilka Lake. The Krishna-Godavari (K-G) Basin is located between Nellore and Kakinada in the central part of the eastern continental margin of India. The NE-SW trending Bapatla Horst and the Tanuku Horst divide this basin into three sub-basins, the Krishna, the West Godavari and the East Godavari. Being a prospective petroliferous basin, several studies have been carried out in the KG Basin to understand the basement configuration and to identify the major structural trends (e.g. Sastri et al., 1973; Kumar, 1983; Mohinuddin et al., 1993; Prabhakar and Zutshi, 1993; Rao, 2001; Bastia, 2006; Gupta, 2006). Rajaram et al. (2000) inferred the presence of NW-SE trending structural features in the offshore regions of the KG Basin, suggesting the continuation of the onshore NW-SE trends offshore, upto the continent-ocean boundary. The Palar Basin is located between the Krishna-Godavari Basin and the Cauvery Basin, with its northern part extending to the offshore. This half crescent shaped basin is bordered in the north by the Nayudupeta High and in the south by the Chingleput High (Mazumder et al., 2013; Prakash et al., 2018; Mazumder et al., 2019). The Palar Basin is dissected into a northern and a southern part by a broadly E-W oriented subsurface ridge, which is considered to have resulted from a post-rift compression. The southern part of the basin shows a N-S trend, while the northern part trends NE-SW (Mazumder et al., 2013). The Cauvery Basin is located in the southeastern part of the Peninsular India. This basin consists of block-faulted basement comprising of horst-graben architecture oblique to the coast, giving rise to several sub-basins separated by NE-SW trending subsurface basement ridges (Sastri et al., 1981). These sub-basins include the Ariyalur-Pondicherry, Tanjavur-Tranquebar, Nagapattinam and Palk Bay Sub-basins, separated respectively by the Kumbhakonam-Madanam, Karaikkal and the Vedaranyam ridges (Sastri et al., 1981; Twinkle et al., 2016; DGH, 2018a). Subsurface mapping carried out in the Cauvery Basin indicate that the Vedaranyam-Tiruchirapalli and the MaduraiRameswaram trends cut across the general NE-SW trending horstgraben structures of the Cauvery Basin (Twinkle et al., 2016). Consequently, the Cauvery Basin is considered to have undergone three major episodes of tectonism that governed the development of basement structures consisting of three major N-S, NE-SW and NWSE trending faults during three different phases (Mazumder et al., 2019).

\section{Deep ocean basins adjacent to the Indian continental margins}

The Indian Ocean consists of several deep basins, some of which have developed at the presently active mid ocean ridges, while the others occurred at now-extinct spreading centres or failed rifts. A detailed understanding on the age of the oceanic crust underlying these ocean basins is essential to decipher the plate tectonic evolution of the Indian Ocean. In this section, I discuss the current status of knowledge of the structure and age of the ocean basins associated with the formation and evolution of the Indian continental margin, following the geomagnetic polarity reversal timescale of Cande and Kent (1995).

\section{Arabian and Eastern Somali basins}

The Arabian and Eastern Somali basins (Figures 1 and 4) are the conjugate ocean basins formed at the Carlsberg Ridge, separating the Laxmi Ridge from the Seychelles Plateau. The oldest magnetic lineation in these basins corresponds to chron C28ny ( 62.5 Ma), located immediately south of the Laxmi Ridge in the Indian side, and north of the Seychelles Plateau in the African side (Chaubey et al., 2002a). Miles and Roest (1993) reported the presence of oblique offsets, which are the diagnostic features of propagating ridge segments, in both these basins. Later studies (Chaubey et al., 1998; Dyment, 1998) established the existence of oblique offsets in these basins with the help of additional magnetic profiles. Based on an upto-date compilation of the marine magnetic profiles from these conjugate basins, Chaubey et al. (2002a) carried out a detailed mapping of the magnetic lineations, pseudofaults and fracture zones between chrons C28ny ( 62.5 Ma) and C20ny (42.54 Ma) from these two conjugate basins. The derived tectonic fabric pattern based on their studies establishes three major episodes of ridge propagation in the Arabian and Eastern Somali basins; the first stage of westward 


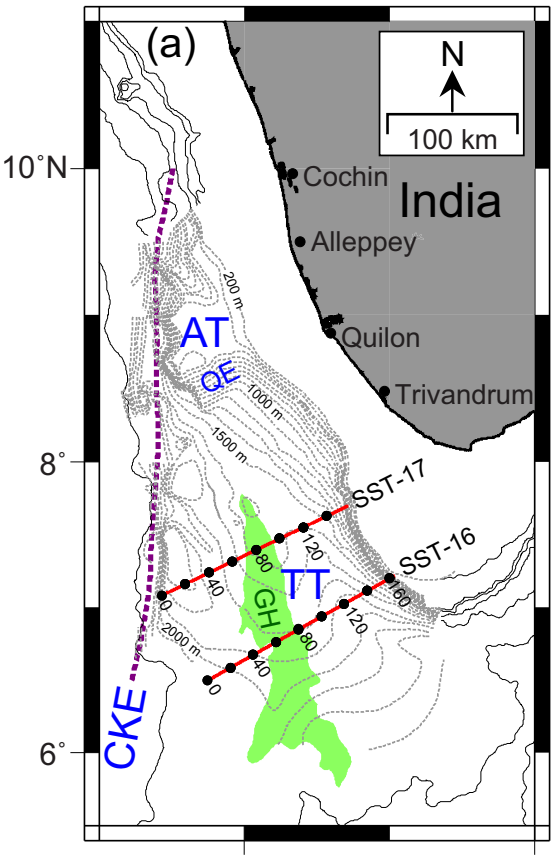

$76^{\circ}$

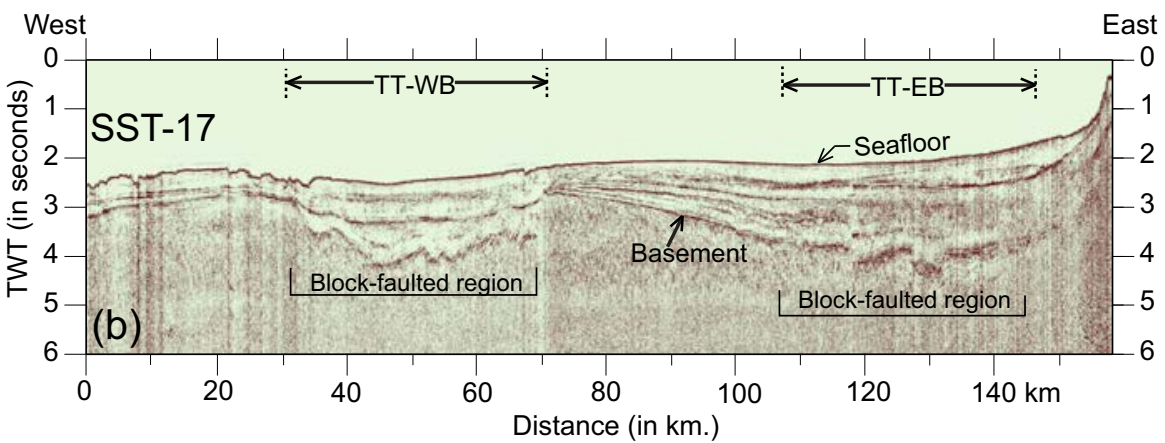

West East

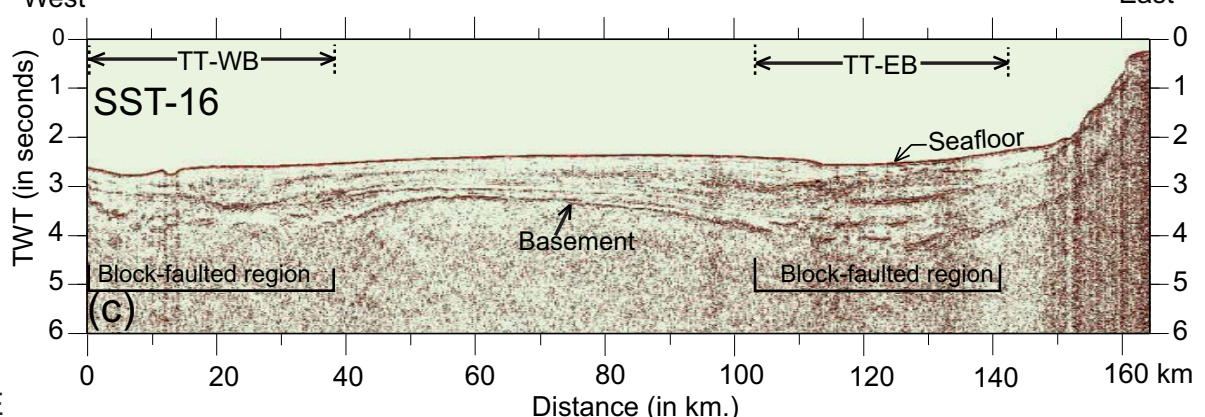

Figure 3. Seafloor and sub-seafloor configurations of the Alleppey-Trivandrum Terrace Complex (ATTC) and the adjacent regions as depicted by (a) bathymetric contours; (b) and (c) multichannel seismic reflection sections along profiles SST-17 and SST-16 (modified after Yatheesh et al., 2013b). The grey continuous lines represent the isobaths obtained from GEBCO (IOC-IHO-BODC, 2003), while the grey dotted lines represents isobaths in $100 \mathrm{~m}$ interval obtained from Yatheesh et al. (2013b). Thick dotted magenta line represents the extent of the Chain-Kairali Escarpment and the green shaded region labelled as GH represents the gravity high zone in the central part of the ATTC. The red lines represent locations of the seismic profiles and the labels along with the dots represent distance in the seismic sections. TT-WB: TT-Western Basin; TT-EB: TT-Eastern Basin

propagation during chrons C28ny ( 62.5 Ma) to C27ny (60.92 Ma), the second stage of eastward propagation during C26r ( 57.91-60.92 $\mathrm{Ma})$ to C25ny ( 55.90 Ma) and the third stage of westward propagation during chron C24r ( 53.35-55.90 Ma) to chron C21ny ( 46.26 Ma).

\section{Laxmi and Gop basins}

The Laxmi Basin is the deep offshore region between the NWSE trending segment of the Laxmi Ridge and the northwestern continental margin of India (Figures 4 and 5). The nature of the crust underlying the Laxmi Basin has been a matter of intense academic debate for many years now. Some authors (e.g. Naini and Talwani, 1982; Kolla and Coumes, 1990; Todal and Eldholm, 1998; Krishna et al., 2006) consider that the Laxmi Basin is underlain by continental crust while others (Biswas and Singh, 1988; Bhattacharya et al., 1994a; Talwani and Reif, 1998; Yatheesh, 2007; Corfield et al., 2010; Eagles and Wibisono, 2013; Siawal et al., 2014; Bhattacharya and Yatheesh, 2015; Ramana et al., 2015; Misra et al., 2015) argue for an oceanic crust. The continental nature of the crust underlying the Laxmi Basin has been inferred on the basis of the semi-continental crustal thickness (e.g. Naini and Talwani, 1982; Krishna et al., 2006), lack of identifiable seafloor spreading type magnetic anomalies (Naini and Talwani, 1982) and extension of Precambrian structural grain into the basin (Kolla and Coumes, 1990). On the other hand, support for its oceanic nature stems from the identification of seafloor spreading-type magnetic anomalies in the basin (Bhattacharya et al., 1994a; Talwani and Reif, 1998; Yatheesh, 2007; Eagles and Wibisono, 2013; Bhattacharya and
Yatheesh, 2015), hyperbolic reflection pattern in the multi-channel seismic reflection sections (Biswas and Singh, 1988) and presence of seaward dipping reflectors (SDRs) to the east of the Laxmi Ridge and to the west of the Indian continental margin, suggesting continentocean boundaries in between (Corfield et al., 2010; Siawal et al., 2014; Misra et al., 2015). The magnetic anomaly sequence in the Laxmi Basin has been interpreted to represent two-limbed seafloor spreading, identified variously as C33n-C28n-C33n (Bhattacharya et al., 1994a), C33n-C27n-C33n (Yatheesh, 2007), C29n-C28n-C29n (Eagles and Wibisono, 2013) and C33r-C28r-C33r (Ramana et al., 2015).

The Gop Basin is the deep offshore region existing between the E-W trending segment of the Laxmi Ridge and the western IndiaPakistan margin (Figures 4 and 5), that was created by the crustal divergence of the Seychelles-Laxmi Ridge continental block from the Saurashtra Volcanic Platform. By and large, this basin has been suggested to be underlain by oceanic crust, based on the presence of well-correlatable magnetic anomalies (Malod et al., 1997; Krishna et al., 2006; Yatheesh, 2007; Collier et al., 2008; Yatheesh et al., 2009), the crustal velocity structure derived from the wide angle seismic reflection data (Collier et al., 2004; Minshull et al., 2008; Collier et al., 2009) and the integrated forward modelling of gravity and magnetic anomalies together with the seismic constraints (Yatheesh, 2007; Yatheesh et al., 2009). Recently however, Rao et al. (2018) have proposed a continental origin for the Gop Basin, based on the derived crustal stretching factor and effective elastic thickness. As in the case of the Laxmi Basin, the magnetic anomaly sequence in the Gop Basin also has been interpreted to represent two-limbed seafloor 


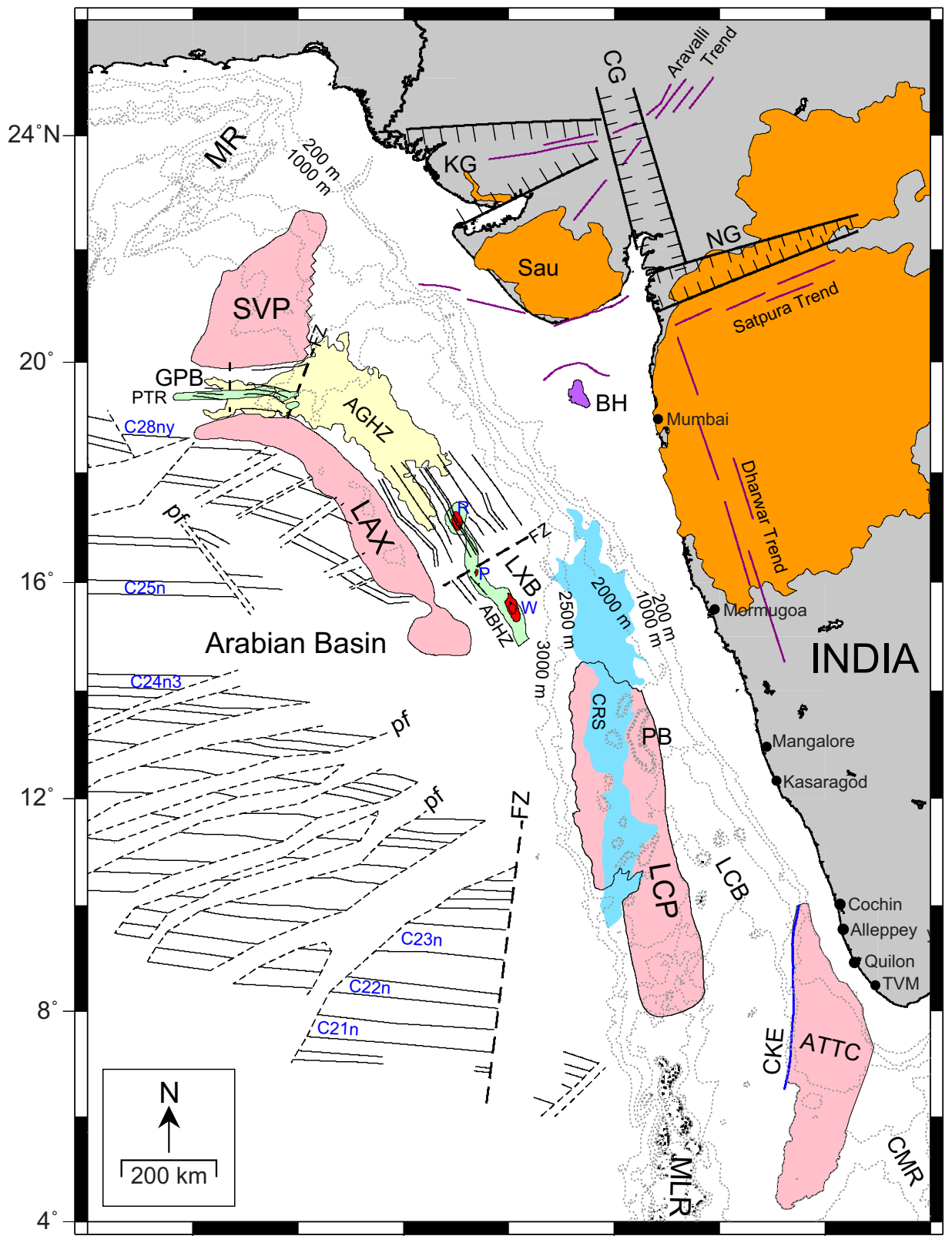

$64^{\circ}$

$68^{\circ}$

a

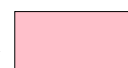

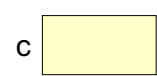

$72^{\circ}$

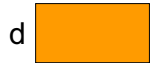

$76^{\circ} \mathrm{E}$

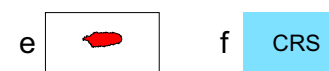

Figure 4. Tectonic fabric map of the western continental margin of India and the adjacent regions (after Bhattacharya and Yatheesh (2015), with permission from Springer Nature). The continuous black lines, thick dashed lines and the dotted lines represent the magnetic lineations, fracture zones and pseudofaults, respectively. The hachured thick black lines represent postulated boundaries of rift graben basins onland and the magenta lines represent onshore and offshore structural trends. ATTC: Alleppey-Trivandrum Terrace Complex; CKE: Chain-Kairali Escarpment; ABHZ: Axial basement high representing the Panikkar Ridge in the Laxmi Basin; PTR: Palitana Ridge; CG: Cambay Rift Graben; KG: Kutch Rift Graben, NG: Narmada Rift Graben; LCP: Laccadive Plateau; MLR: Maldive Ridge; CMR: Comorin Ridge; PB: Padua Bank; LXB: Laxmi Basin; GPB: Gop Basin; LCB: Laccadive Basin; Sau: Saurashtra; TVM: Trivandrum; MR: Murray Ridge; SVP: Saurashtra Volcanic Platform; BH: Bombay High; Explanation of items of the legend - (a) Continental slivers; (b) Extent of axial basement high zones representing the extinct spreading centres in the Laxmi and Gop basins; (c) anomalous gravity high zone (AGHZ); (d) extents of Deccan Flood Basalts; (e) Seamounts in the Laxmi Basin, R Raman Seamount; P Panikkar Seamount; W Wadia Guyot; ( $f$ ) Cannanore Rift System.

spreading with varied identifications as C29r-C29n-C29r (Malod et al., 1997), C32n.1r-C31r-C32n.1r (Collier et al., 2008), C29r or C31r (Minshull et al., 2008), C31r-C25r-C31r or C29r-C25rC29r (Yatheesh et al., 2009) and C33rC31r-C33r (Ramana et al., 2015).

Recently, Bhattacharya and Yatheesh (2015) evaluated all the existing magnetic anomaly identifications in the Laxmi and Gop basins and concluded that the magnetic anomaly sequence in the Laxmi Basin represents C30n-C25r-C30n sequence and those in the Gop Basin represents C29r-C25r-C29r sequence, with the locations of their extinct spreading centres coinciding with the Panikkar and the Palitana Ridges, respectively (Figure 5). They postulated the existence of a fossil triple junction, referred to as the Gop-Narmada-Laxmi (GNL) Triple Junction located off Saurashtra Peninsula, based on the pattern and age of the magnetic lineations in the two basins. Furthermore, they provided detailed plate reconstructions maps to depict the evolution of the Gop Basin, Laxmi Basin and the Narmada Rift, whose axes of divergence represent the three arms of this triple junction (Figure 5).

\section{Laccadive Basin}

The Laccadive Basin is the deep ocean basin existing between the southwestern continental margin of India and the Laccadive Plateau (Figure 4), which represent the northernmost segment of the Laccadive-Chagos Ridge.. The bathymetric map of the Laccadive Basin shows the presence of several isolated highs located over a continuous subsurface ridge, referred to as the Prathap Ridge (Naini, 1980). This inferred ridge is considered to have been formed either by Rèunion Hotspot volcanism (Krishna et al., 1992) or by riftphase volcanism related to IndiaMadagascar separation (Subrahmanyam et al., 1995). The nature of crust underlying the Laccadive Basin has not yet been confidently established. Chaubey et al. (2002b) considered this basin to represent a failed rift with volcanism on a stretched continental regime, based on their deductions of rotated fault blocks akin to half graben. Considering the presence of seaward 


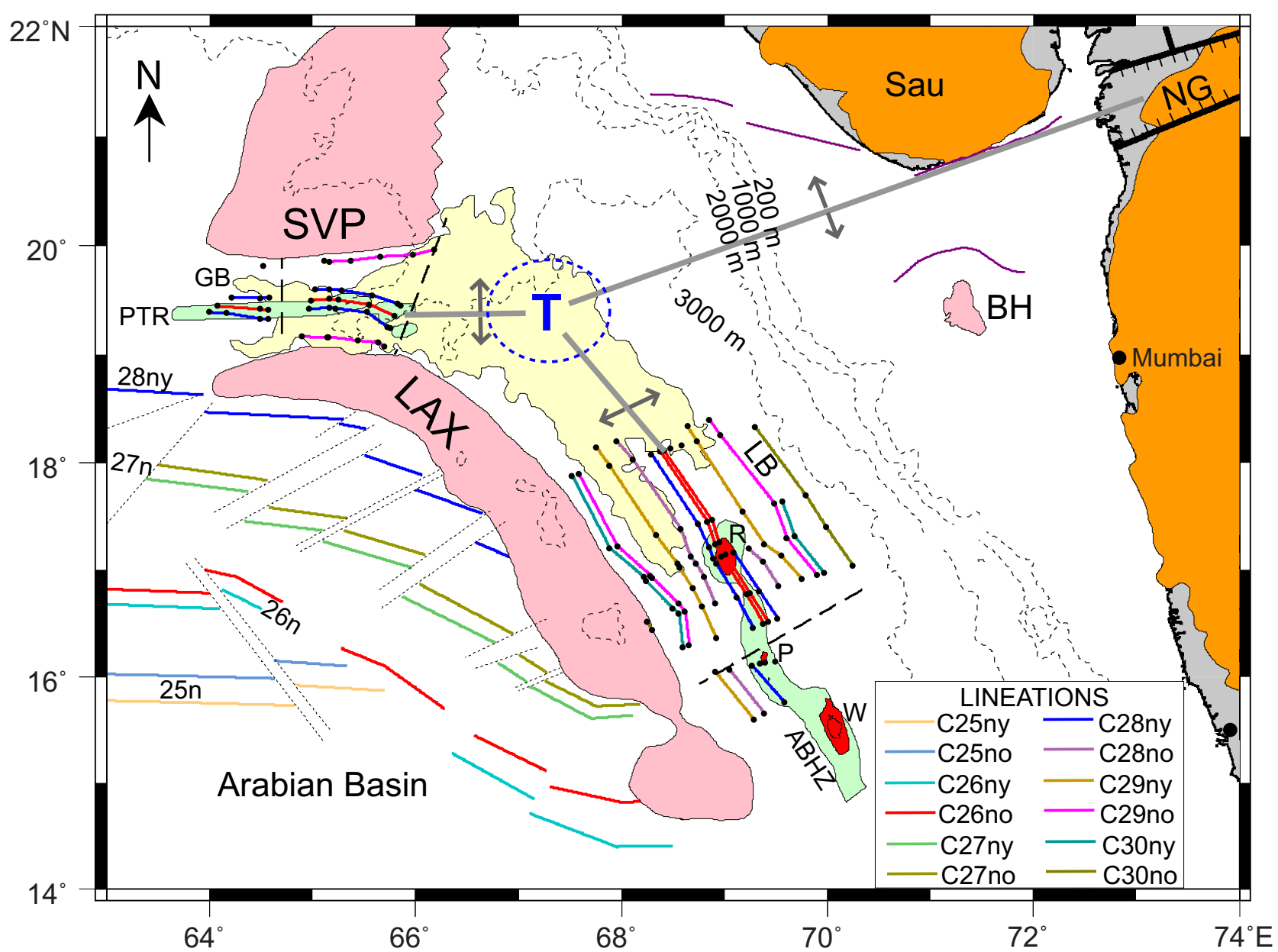

Figure 5. Generalized map of the deep offshore regions adjoining the northern segment of the western continental margin of India, showing the major tectonic elements (after Bhattacharya and Yatheesh (2015), with permission from Springer Nature). Solid coloured lines represent the mapped seafloor spreading type magnetic lineations inferred in the Laxmi, Gop and Arabian basins and the thin dotted lines oblique to the magnetic lineations represent pseudofaults. The yellow shaded region represents an anomalous gravity high zone. T: postulated Gop-Narmada-Laxmi (GNL) fossil triple junction off Saurashtra Peninsula; Other details are as in Figure 4.

dipping reflectors (SDRs) west of the Laccadive Plateau and the derived crustal configuration from the forward modelling of the gravity data, Ajay et al. (2010) inferred that the continent-ocean boundary in this region lies west of the Laccadive Plateau implying that the Laccadive Basin is continental in nature. Yatheesh et al. (2013b) demonstrated that the Laccadive Basin region could be explained either in terms of a much thinned continental crust or as anomalously thick oceanic crust, based on forward modelling of the gravity profiles.

\section{Mannar Basin}

Mannar Basin is the deep offshore region between Sri Lanka and the southeastern part of India (Figure 2). This triangular shaped basin is narrower in the north, widening southwards. Mannar 1-1A and Pearl-1 are the first drill wells located respectively in the Indian and Sri Lankan sectors of the Mannar Basin (Premarathne et al., 2013). Stratigraphic section of the Pearl-1 well shows the existence of $\sim 2.9$ km Upper Cretaceous to Recent sediments on an igneous basement. This latter has led to a hypothesis that the Mannar Basin is underlain by oceanic crust. In contrast however, based on interpretations of the seismic data, Baillie et al. (2002) inferred the occurrence of sediments beyond this igneous rock. This was later confirmed with the stratigraphic column of another deep drill well, the Barracuda-1G/1, which penetrated about $760 \mathrm{~m}$ thick basaltic rock. This igneous rock is overlain by shale, which continues down to the bottom of the Barracuda well. The age of this volcanics was estimated to be $\sim 76.8$ Ma and consequently, the volcanics interbedded in the sediments was considered to be the result of several episodes of volcanism related to the onset of rifting and subsequent northward drift of India (Rana et al., 2008; Premarathne et al., 2013). Subsequently, based on the forward and inverse modelling of the satellite-derived free-air gravity anomalies, Herath et al. (2017) inferred that the Moho is elevated beneath the Mannar Basin with a minimum depth of about $16 \mathrm{~km}$ and extending to a depth of about $36 \mathrm{~km}$ on either sides of the basin, as a failed rift.

\section{Central Indian, Crozet and Madagascar basins}

The Central Indian, Crozet and Madagascar basins (Figure 1) constitute the Central Indian Ocean, formed by seafloor spreading at the Southeast Indian and Central Indian ridges. The Rodrigues Triple Junction trace divides the Central Indian Basin into to the Western Central and the Eastern Central Indian basins. The Eastern Central Indian and the Crozet basins represent conjugate basins formed at 
the Southeast Indian Ridge, while the Western Central Indian and the Madagascar basins are the conjugate basins formed at the Central Indian Ridge. Geomagnetic investigations (Fisher et al., 1971; Sclater and Fisher, 1974; Royer and Schlich, 1988; Kamesh Raju and Ramprasad, 1989; Dyment, 1993; Kamesh Raju, 1993; Krishna et al., 1995; Yatheesh et al., 2008; Cande et al., 2010; Yatheesh et al., 2013a; Cande and Patriat, 2015; Yatheesh et al., 2019) carried out in these basins suggest that the conjugate Eastern Central Indian and Crozet basins contain the magnetic lineation sequence C34ny-C1n (83.0 to $0.0 \mathrm{Ma}$ ), while the conjugate Western Central Indian and the Madagascar basins contain the magnetic lineation sequence C30nyC1n ( 65.58 to 0.0 Ma). The magnetic lineations in these basins are divided into several compartments offset by fracture zones, such as the Vishnu, Northern Astrolabe, Northern Boussole and the $86^{\circ} \mathrm{E}$ fracture zones (FZ) in the Central Indian Basin; the Mauritius and the Southern Boussole fracture zones in the Madagascar Basin; and the Southern Astrolabe FZ in the Crozet Basin, besides several other unnamed fracture zones. The oceanic crust in the Central Indian Basin has been suggested to be undergoing intraplate deformation resulting from high stresses in the oceanic lithosphere due to the plate boundary configuration and the ongoing collision of India with Eurasia (Royer and Gordon, 1997; Deplus et al., 1998; Krishna et al., 2001). This deformation is considered to have initiated at $\sim 11.0 \mathrm{Ma}$ (Royer et al., 1997).

\section{Bay of Bengal and Enderby Basin}

The Bay of Bengal is bordered by the eastern continental margin of India and Bangladesh in the west/north and the Sunda-Java Trench to the east (Figure 1). Ramana et al. (1994) identified NNW-SSE trending Mesozoic magnetic anomaly sequence M11-M0 (132.5 to $118 \mathrm{Ma}$ ) in the Bay of Bengal. Subsequently, Ramana et al. (2001) also identified M11-M0 sequence of magnetic anomalies in the Enderby Basin and inferred that both these basins represent conjugate basins formed by seafloor spreading between India and Antarctica during Early Cretaceous. Following this, Desa et al. (2006) identified magnetic anomaly sequence M11-M0 (132.5 to $118 \mathrm{Ma}$ ) in the region between Comorin Ridge and the $85^{\circ} \mathrm{E}$ Ridge, south off Sri Lanka. Subsequently, Gaina et al. (2007) identified both the flanks of oceanic crust with magnetic anomaly sequence M9no to M2no ( 130.2 to 124.1 Ma) in the Enderby Basin, establishing the existence of an extinct spreading axis within the Enderby Basin. Krishna et al. (2009) revisited the magnetic anomaly identifications in the Bay of Bengal and Enderby Basin and inferred that the oceanic crust in the Bay of Bengal has been generated during the Cretaceous long normal superchron. Subsequently, Radhakrishna et al. (2012a) inferred the presence of oceanic crust younger to M4 in southern Bay of Bengal and younger to M2 in the northern Bay of Bengal along the eastern continental margin of India. Gibbons et al. (2013) revisited the magnetic anomaly identifications in the Eastern Enderby Basin and revised the identification of magnetic anomalies to represent M4-M0 ( 126.7-120.4 Ma) sequence. Talwani et al. (2016) identified the conjugate magnetic anomaly sequences M12n-M0n (132.0 to 120.4 $\mathrm{Ma}$ ) in the Western Basin of the Bay of Bengal and the Western Enderby Basin. According to them, with the arrival of the Kerguelen Hotspot at around M0 time, reorganization of spreading occurred and a new spreading axis opened at or close to the line joining the Rajmahal and Sylhet traps. Based on the existence of the prominent magnetic anomaly doublet connecting the Rajmahal and Sylhet traps, combined with the inferred location of the seaward dipping reflectors, they defined the new line along which seafloor spreading initiated after $118 \mathrm{Ma}$, forming the oceanic crust underlying Bangladesh and the Eastern Basin of the Bay of Bengal. The seaward dipping reflectors representing the continent-ocean boundary lies onshore Bangladesh due to the later deposition of enormous sediments derived from Himalayan orogeny.

\section{Mascarene Basin}

The Mascarene Basin (Figure 6) resulted from the breakup of India-Seychelles-Madagascar continental block and subsequent plate tectonic evolution. This basin can be divided into Southern and

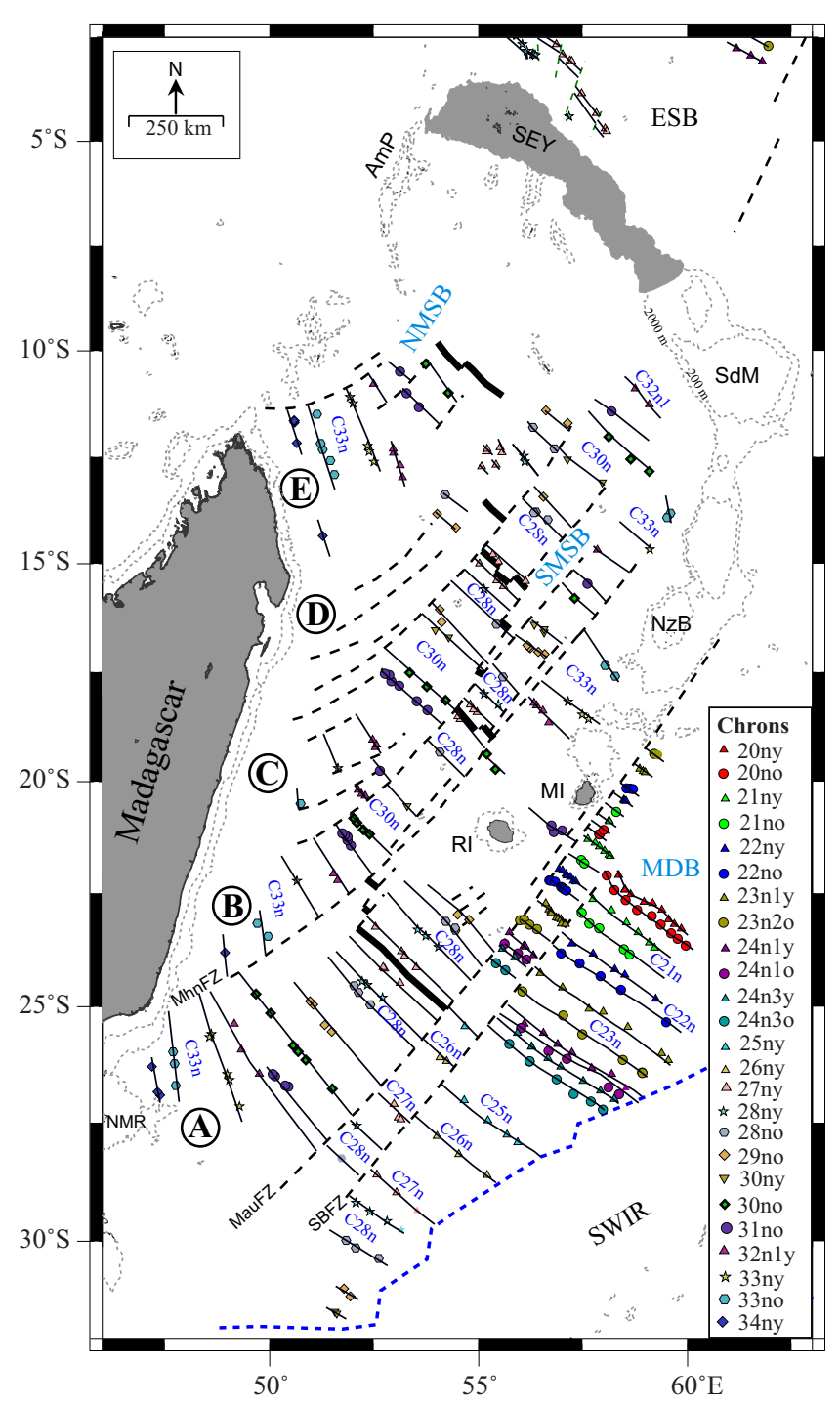

Figure 6. Tectonic fabric map of the eastern continental margin of Madagascar and the adjacent deep offshore regions (after Shuhail et al. (2018), with permission from Elsevier). The thick black lines represent extinct spreading axis. The compartments from $A$ to $D$ fall in the Southern Mascarene Basin (SMSB) and the compartment E falls within the Northern Mascarene Basin (NMSB). NMR: Northern Madagascar Ridge; SEY: Seychelles Plateau; MauFZ: Mauritius Fracture Zone: MhnFZ: Mahanoro Fracture Zone; SBFZ: Southern Boussole Fracture Zone. Other details are as in Figures 1 and 4. 
Northern Mascarene basin. Whereas the Southern Mascarene Basin formed by the divergence between Madagascar and India, the Northern Mascarene Basin formed from the divergence between Madagascar and Seychelles (Bernard and Munschy, 2000; Bhattacharya and Yatheesh, 2015; Shuhail et al., 2018). The southern and northern domains of the Mascarene Basin contain the magnetic anomaly sequence of C34ny-C27ny-C34ny (83.0 to 60.92 Ma) and C34nyC30no-C34ny (83.0 to 67.61 Ma), respectively (Dyment, 1991; Bernard and Munschy, 2000; Eagles and Wibisono, 2013; Bhattacharya and Yatheesh, 2015; Shuhail et al., 2018). The nearly NW-SE trending magnetic lineations in both these domains are offset by several nearly NE-SW trending long fracture zones. In the Southern Mascarene Basin, the entire sequence of magnetic lineations C34nyC27ny have been mapped on both the flanks of the oceanic crust. In contrast however, in the Northern Mascarene Basin, the magnetic anomaly sequence C34ny-C30no have been mapped only on the southern flank (the Madagascar side). The two major fracture zones identified in the Mascarene Basin are the Mahanoro FZ and Mauritius FZ (Figure 6), both of which are important features in constraining the India-Madagascar initial breakup and subsequent evolution of the Western and Central sectors of the Indian Ocean.

\section{Wharton Basin}

The Wharton Basin (Figure 1) was created by seafloor spreading at the Indian-Australian plate boundary. Several workers (e.g. Sclater and Fisher, 1974; Schlich, 1982; Liu et al., 1983; Krishna et al., 2012; Jacob et al., 2014) have studied and mapped the magnetic lineations and the associated tectonic fabric in the Wharton Basin. These magnetic lineation patterns indicate that the basin consists of both the flanks of oceanic crust containing the magnetic anomaly sequence C34ny-C20ny (83.0 to $42.54 \mathrm{Ma}$ ), representing thereby, an extinct spreading centre, however, some part of the oldest oceanic crust in the northern flank has already been subducted through the SundaJava Trench. These magnetic lineations are offset by $\sim \mathrm{N}-\mathrm{S}$ trending long fracture zones. The cessation of spreading in the basin is considered to have occurred at around 36.5 Ma (Jacob et al., 2014).

\section{Aseismic ridges/submarine plateaus}

The Indian Ocean consists of several aseismic ridges / submarine plateaus (Figure 1), most of which are generally considered to have been formed by hotspot volcanism. The features in the Western Indian Ocean comprise the Laxmi Ridge, Laccadive-Chagos Ridge, Comorin Ridge, Seychelles-Mascarene Plateau and the Madagascar Ridge, while those in the Eastern Indian Ocean include the $85^{\circ} \mathrm{E}$ Ridge and the Ninetyeast Ridge.

\section{Laxmi Ridge}

The Laxmi Ridge is an aseismic basement high located off the northwestern continental margin of India (Figures 4 and 5). This feature, which is characterized by a gravity low signature, consists of a NW-SE and an E-W trending segment bordering the seaward side of the Laxmi and Gop basins, respectively. There is a broad agreement among the researchers that the Laxmi Ridge is underlain by continental crust (Naini and Talwani, 1982; Bhattacharya et al., 1994a; Talwani and Reif, 1998; Collier et al., 2004; Krishna et al., 2006; Yatheesh, 2007; Collier et al., 2008; Minshull et al., 2008; Collier et al., 2009;
Bhattacharya and Yatheesh, 2015; Nair et al., 2015; Mishra et al., 2018). This inference is primarily based on the crustal velocity-depth structure (Naini and Talwani, 1982; Collier et al., 2004; Minshull et al., 2008; Collier et al., 2009), crustal configuration based on seismicconstrained gravity modeling (Krishna et al., 2006; Yatheesh, 2007; Yatheesh et al., 2009; Nair et al., 2015), admittance analysis (Mishra et al., 2018) and the presence of seaward dipping reflectors (SDRs) on both the landward and seaward sides of the Ridge (Corfield et al., 2010; Calvès et al., 2011; Siawal et al., 2014). Todal and Eldholm (1998) however, inferred that the Laxmi Ridge is a marginal high complex, comprising both continental and oceanic crusts. Based on the high-resolution and deep penetrated seismic reflection data, Misra et al. (2015) recently concluded that the Laxmi Ridge is composed of oceanic crust formed at an extinct spreading centre.

\section{Laccadive-Chagos Ridge}

The Laccadive-Chagos Ridge is an $2500 \mathrm{~km}$ long aseismic bathymetric high (Figure 1) located between $12^{\circ} \mathrm{S}$ and $14^{\circ} \mathrm{N}$ latitudes in the Western Indian Ocean. This slightly arcuate elongated feature is divisible into three main segments, the Laccadive Plateau, Maldive Ridge and the Chagos Bank, separated by relatively deep saddle-like features (Bhattacharya and Chaubey, 2001). Hypotheses on the origin of the Laccadive-Chagos Ridge range from a leaky transform fault (Fisher et al., 1971; Sclater and Fisher, 1974), to a hotspot trail (Dietz and Holden, 1970; Whitmarsh, 1974), composite structural elements of various origins (Avraham and Bunce, 1977), and to a product of crack propagation (Sheth, 2005). Though the hotspot hypothesis appears to have a broader acceptance for the genesis of the LaccadiveChagos Ridge as a whole, several evidences point out the possibility of a continental origin for the Laccadive Plateau segment. This inference is mainly based on the estimated crustal thickness from seismic refraction experiments (Naini and Talwani, 1982), presence of clearly identifiable rotated fault blocks that represents extensional tectonic events (Murty et al., 1999), presence of a complex basement structure comprising of single normal faults with half grabens and grabens, referred to as the Cannanore Rift System (Bhattacharya and Yatheesh, 2015; DGH, 2018b), presence of seaward dipping reflectors (SDRs) west of the Laccadive Plateau (Ajay et al., 2010), crustal configuration derived from the forward modelling of gravity data (Chaubey et al., 2002b; Ajay et al., 2010; Nair et al., 2013) and the admittance analysis of gravity and bathymetry data (Chaubey et al., 2008). Recently, based on the three-dimensional inversion of gravity anomalies, Kunnummal et al. (2018) inferred that the Greater Maldive Ridge, which consists of the Maldive Ridge, deep sea channel and northern limit of the Chagos Bank, is underlain by $22 \mathrm{~km}$ thick crust representing either oceanic crust with magmatic underplating or continental crust.

\section{Comorin Ridge}

The Comorin Ridge is a NNW-SSE trending bathymetric high located southeast of the Alleppey-Trivandrum Terrace Complex (Figures 1 and 4). The topography of this $\sim 500 \mathrm{~km}$ long aseismic ridge is defined by 3900 and $2900 \mathrm{~m}$ isobaths. The western flank of the Comorin Ridge dips gently, while its eastern side is characterized by a steep scarp. Based on the integrated analysis of bathymetry, gravity and single-channel seismic reflection data, Kahle et al. (1981) considered that the Comorin Ridge was formed on an oceanic crust 
and the eastern edge of the ridge denote the boundary between this oceanic crust and the adjacent rifted continental crust. On the other hand, based on the admittance analysis and forward modelling of gravity data, Sreejith et al. (2008) inferred that the southern part of the ridge was emplaced on the relatively weak oceanic crust, while the northern part was emplaced on a continental crust.

\section{Seychelles-Mascarene Plateau}

The Seychelles-Mascarene Plateau is a 2600 km long, arcuate feature consisting of the Amirante Plateau, Seychelles Bank, Seychelles-Saya de Malha Saddle, Mascarene Plateau (comprising of the Saya de Malha Bank, Nazareth Bank, Cargados-Carajos Bank and the Mauritius Island) and the Rèunion Island (Figures 1 and 6). Among these, the continental nature of the crust underlying the Seychelles Bank has been established based on the geochronological (Baker and Miller, 1963) and seismic refraction (Plummer and Belle, 1995) investigations. Bhattacharya and Yatheesh (2015) considered that the continental crust underlying the Seychelles Bank extends further southeast to a part of the Seychelles-Saya de Malha saddle. This entire region of the continental crust has been considered by them to represent the Seychelles Plateau continental sliver, which was developed after a series of tectonic events related to India-Laxmi Ridge-Seychelles-Madagascar breakup. On the other hand, the Mascarene Plateau is considered to have been formed by hotspot volcanism, as evidenced by the north to south age progression of the samples obtained from Saya de Malha and the Nazareth Bank (Duncan, 1990). The radiometric results from the ODP 115 leg drill suggest that the Mauritius Island is an eroded volcanic island formed by the Réunion Hotspot activity (Duncan and Hargraves, 1990). Recently, based on the age of zircon xenocrysts recovered from the Mauritian beach sands, Torsvik et al. (2013) suggested that the Mauritius Island and the other segments of the Mascarene Plateau may overlie a Precambrian basement of continental origin, referred to as the Mauritia microcontinent.

\section{Madagascar Ridge}

The Madagascar Ridge is a N-S trending bathymetry high extending south of the Madagascar Island (Figure 1). This aseismic ridge separates the Mozambique and Madagascar basins and abuts the Southwest Indian Ridge to the South. The Madagascar Ridge consists of a northern and a southern domain, separated at the $31^{\circ} \mathrm{S}$ latitude (Goslin et al., 1980). The crust underlying the Northern Madagascar Ridge is considered to be anomalous as it has neither purely continental nor oceanic affinity (Bhattacharya and Chaubey, 2001). Many workers (Yatheesh et al., 2006; Yatheesh et al., 2013b; Bhattacharya and Yatheesh, 2015) consider the bathymetric notch defined by 2000 m isobath on the Northern Madagascar Ridge as representing the conjugate of the Alleppey-Trivandrum Terrace Complex located in the southwestern continental margin of India. The velocity-depth structure of the Southern Madagascar Ridge is closely related to that of mean oceanic crust (Goslin et al., 1981).

\section{$85^{\circ}$ E Ridge}

The $85^{\circ} \mathrm{E}$ Ridge is an anomalous basement high feature located in the Bay of Bengal, buried under the sediments in the north and exposed intermittently above the seafloor to the south (Figure 7).

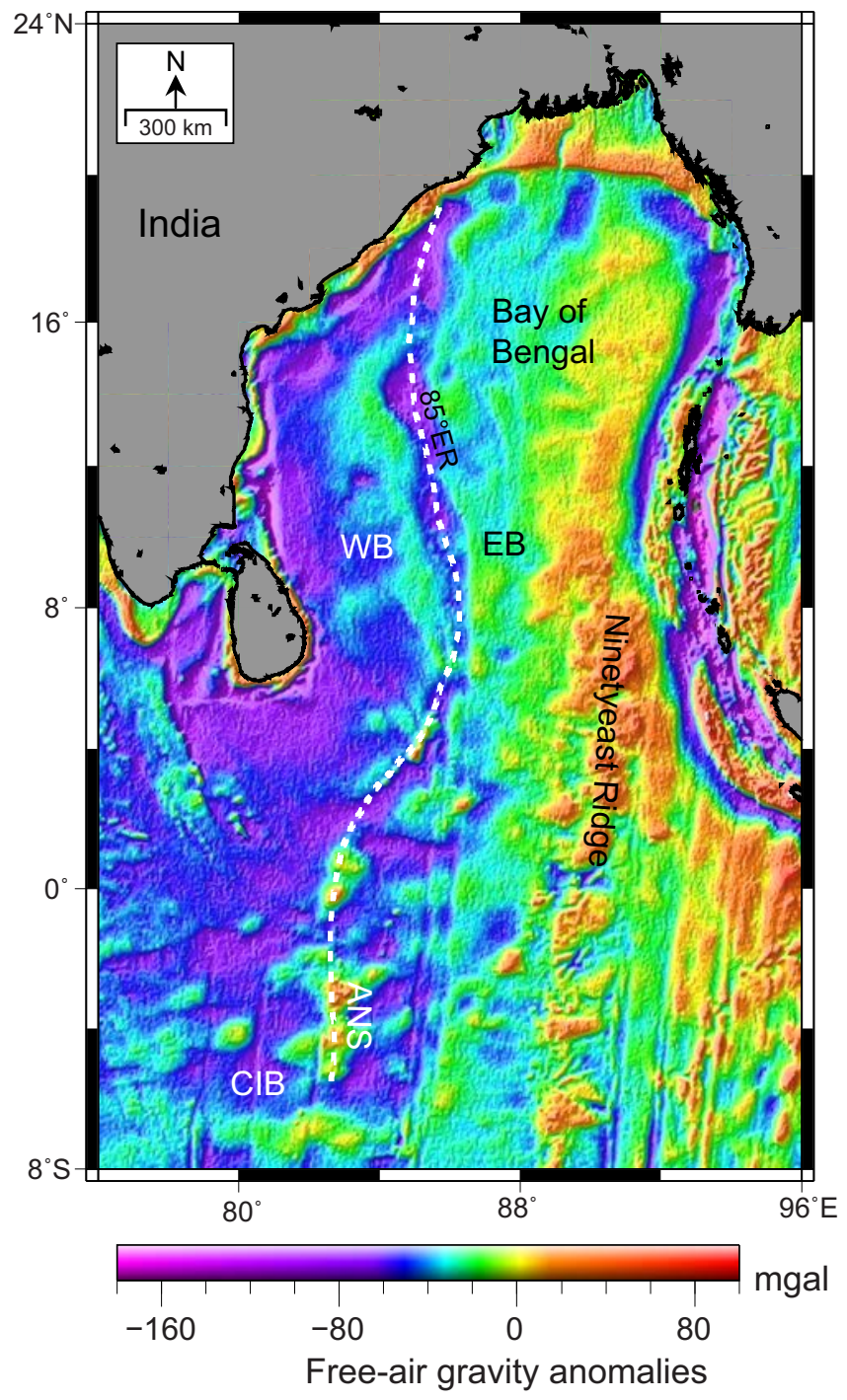

Figure 7. The satellite-derived free-air gravity anomaly map of the central and eastern sectors of the Indian Ocean, showing the locations, trends and gravity signatures of the $85^{\circ} \mathrm{E}$ Ridge, Ninetyeast Ridge and the Afanasy-Nikitin Seamount. The thick dashed white line represents the postulated extent of the $85^{\circ} \mathrm{E}$ Ridge. WB: Western Basin; EB: Eastern Basin; CIB: Central Indian Basin; ANS: Afanasy-Nikitin Seamount.

The northern part of this aseismic ridge is associated with a gravity low signature with variable widths of $100-180 \mathrm{~km}$ and a steeply dipping western flank compared to the eastern flank. Towards north, this ridge continues up to the Mahanadi coast at Chilka Lake (Rao and Radhakrishna, 2014). Towards south, the $85^{\circ} \mathrm{E}$ Ridge is associated with a positive gravity anomaly, extending till the Afanasy-Nikitin Seamount (Krishna, 2003; Sreejith et al., 2011). Hypotheses about the origin of this ridge range from a hotspot trace (Curray and Manasinghe, 1991; Michael and Krishna, 2011; Sreejith et al., 2011), to the effect of horizontal compressive forces (Ramana et al., 1997; Anand et al., 2009), to a continental origin (Sar et al., 2009), leaky transform fault (Gibbons et al., 2013) and a fracture zone (Talwani et al., 2016). Michael and Krishna (2011) inferred the presence of alternate bands of positive and negative magnetic anomaly signatures over the $85^{\circ} \mathrm{E}$ Ridge and dated these anomalies to represent 80-55 Ma. Based on the effective elastic thickness estimate and the flexural 
modelling, Rao et al. (2016) inferred that the $85^{\circ} \mathrm{E}$ Ridge was emplaced in off-ridge environment. Recently, based on the detailed analysis of high resolution and deep-penetration multi-channel seismic reflection sections, Ismaiel et al. (2017) delineated the internal structure of the $85^{\circ} \mathrm{E}$ Ridge and inferred this feature to represent a volcanic construct built by both subaqueous and multiphase submarine volcanisms.

\section{Ninetyeast Ridge}

The Ninetyeast Ridge is a $\sim 5600 \mathrm{~km}$ long, N-S trending, linear volcanic feature extending from $34^{\circ} \mathrm{S}$ to $17^{\circ} \mathrm{N}$ latitudes (Figure 7). South of $10^{\circ} \mathrm{N}$, the Ninetyeast Ridge is clearly discernible as a seafloor feature, however, towards north this feature is entirely buried under the thick Bengal Fan sediments. This feature with an average width of $\sim 200 \mathrm{~km}$ and a height of $2000 \mathrm{~m}$ from its surroundings along most of its length (Krishna et al., 2012), is associated with a positive residual geoid/gravity anomaly (Sreejith et al., 2013). The Ninetyeast Ridge separates the Central Indian Basin from its west to the Wharton Basin to the east (Sclater and Fisher, 1974). It has been widely accepted that the Kerguelen Hotspot located beneath the Indian Plate resulted in the accretion of the Ninetyeast Ridge during the first major plate reorganization that occurred at around 90 Ma (Duncan, 1978). The basalts recovered from the Ninetyeast Ridge by DSDP and ODP drilling range in age from $\sim 82$ to $\sim 37 \mathrm{Ma}$, with a decrease in age from north to south (Coffin et al., 2002). Based on the comparison of age of the oceanic crust to the east and west of the Ninetyeast Ridge, combined with the radiometric ages at the DSDP and ODP sites, Krishna et al. (2012) inferred that the Ninetyeast Ridge lengthened at a rate twice that of adjacent oceanic crust.

\section{Seamounts}

Seamounts on the ocean floor are generally assumed to record the passage of the oceanic crust over the loci of magma generation (Bhattacharya and Chaubey, 2001). The various geophysical investigations carried out in the Indian Ocean reveal the presence of several seamounts in the deep offshore regions. However, to date, only a few of them have been systematically mapped to understand their geomorphology and the geophysical characteristics. These seamounts include the Error Seamount, Sagar Kanya Seamount, Raman-Panikkar-Wadia seamount chain and the Afanasy-Nikitin Seamount, as well as several other un-named seamounts in the Laccadive and the Central Indian basins. The Error Seamount, located in the northwestern boundary of the Carlsberg Ridge, is about $42 \mathrm{~km}$ long and $16 \mathrm{~km}$ wide with an elevation of $4000 \mathrm{~m}$ (Ramana et al., 1987). The Sagar Kanya Seamount, which has a height of $2464 \mathrm{~m}$ and is located in the Arabian Basin about $200 \mathrm{~km}$ west of the Laccadive Plateau, is considered to have been formed by Rèunion Hotspot volcanism (Bhattacharya and Subrahmanyam, 1991). The Raman Seamount, Panikkar Seamount and the Wadia Guyot are three prominent seamounts (Figure 5) located in the axial part of the Laxmi Basin, with basal areas and heights ranging from 300 to $1200 \mathrm{~km}^{2}$ and 1068 to $2240 \mathrm{~m}$, respectively. These features, which together form a $\mathrm{N} 30^{\circ} \mathrm{W}$ trending linear seamount chain of about $250 \mathrm{~km}$ length, is considered to have been formed by an episode of anomalous volcanism resulting from the interaction of the Rèunion Hotspot with the waning spreading centre in the Laxmi Basin (Bhattacharya et al., 1994b; Bhattacharya and Yatheesh, 2015), coeval with the formation of Ghatkopar-Powai tholeiites on the Indian mainland (Pande et al., 2017). Further south, Bijesh et al. (2018) identified and mapped several bathymetric highs in the Laccadive Basin and the adjacent regions of Laccadive Plateau and southwestern continental margin of India. They classified these features as seamounts, hills, knolls, plateaus and guyots. Similarly, Das et al. (2005) identified several seamounts located in the Central Indian Basin region of latitudes $9^{\circ} \mathrm{S}$ to $16^{\circ} \mathrm{S}$ and longitudes $72^{\circ} \mathrm{E}$ to $80^{\circ} \mathrm{E}$.

A major seamount located in the Central Indian Ocean is the Afanasy-Nikitin Seamount, which is a $2000 \mathrm{~m}$ high, $400 \mathrm{~km}$ long and $150 \mathrm{~km}$ wide feature located between $2^{\circ} \mathrm{S}$ and $6^{\circ} \mathrm{S}$ latitudes along $\sim 83^{\circ} \mathrm{E}$ longitude (Krishna, 2003; Krishna et al., 2014). Earlier studies (Curray and Manasinghe, 1991; Krishna, 2003) considered the Afanasy-Nikitin Seamount and the $85^{\circ} \mathrm{E}$ Ridge as representing two continuous parts of the same linear ridge system formed by the same hotspot volcanism; however, recently Krishna et al. (2014) inferred that these features are unrelated and the proximity of the southern end of the $85^{\circ} \mathrm{E}$ Ridge to the Afanasy-Nikitin Seamount is merely coincidental.

\section{Formation and evolution of the continental margins of India and the adjacent deep ocean basins}

The large-scale plate tectonic evolution models (McKenzie and Sclater, 1971; Norton and Sclater, 1979; Besse and Courtillot, 1988) for the Indian Ocean suggest that the formation and evolution of the continental margins of India can be described in terms of rifting and drifting among India, Antarctica, Sri Lanka, Madagascar and Seychelles. However, recent studies (Yatheesh, 2007; Gibbons et al., 2013; Bhattacharya and Yatheesh, 2015; Shuhail et al., 2018, etc.) have considered various identified microcontinental slivers in the Indian Ocean and have attempted to provide detailed plate tectonic evolution for the different sectors of the Indian Ocean and the adjacent continental margins by including the slivers as well, as intervening microcontinental blocks. Furthermore, considering that the evolution of the western continental margin of India involves the formation and evolution of a triple junction as well, it becomes necessary to consider the Indian continental block as two separate blocks, the Southern Indian Protocontinent (SIP) and the Northern Indian Protocontinent (NIP), with the Saurashtra Volcanic Platform (SVP) forming a part of the NIP. Consequently in this section, an updated concept on the formation and evolution of the continental margins of India and the adjacent ocean basins has been provided in eight stages (Figures 8a-h), comprising the breakup and evolution among the Southern Indian Protocontinent (SIP), Northern Indian Protocontinent (NIP), Antarctica (ANT), Sri Lanka (SLK), Australia (AUS), Madagascar (MAD) and Seychelles (SEY), along with the identified microcontinental blocks of the Elan Bank (ELB), Laxmi Ridge (LAX), Laccadive Plateau (LCP) and the Saurashtra Volcanic Platform (SVP).

\section{(a) Separation of ANT-AUS block from ELB-SIP- NIP-SLK-LAX-LCP-SEY-MAD block:}

The separation of ELB-SIP-NIP-SLK-LAX-LCP-SEY-MAD block from ANT-AUS block appears to have initiated sometime around $132 \mathrm{Ma}$, creating the Western Basin in the Bay of Bengal on the Indian side and its conjugate Western Enderby Basin on the Antarctic 

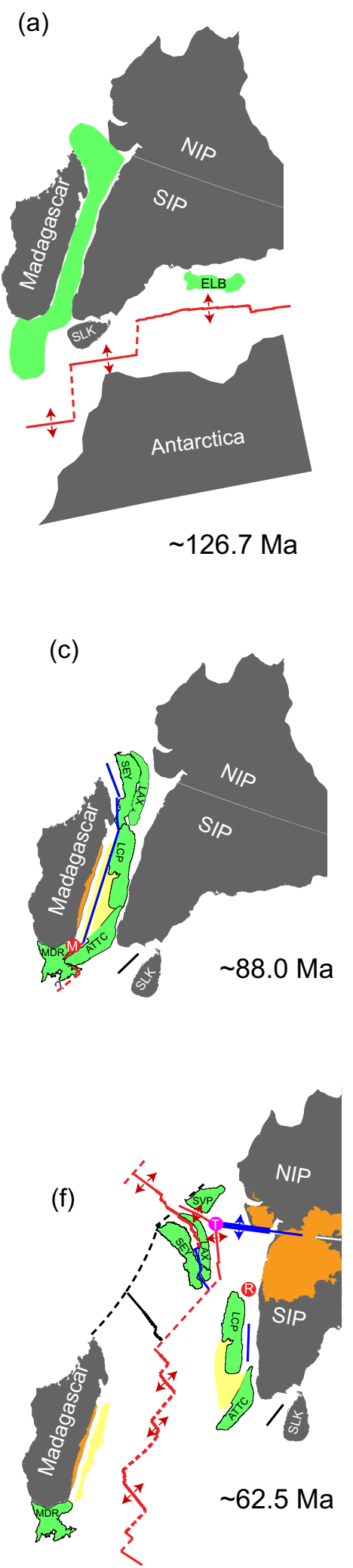
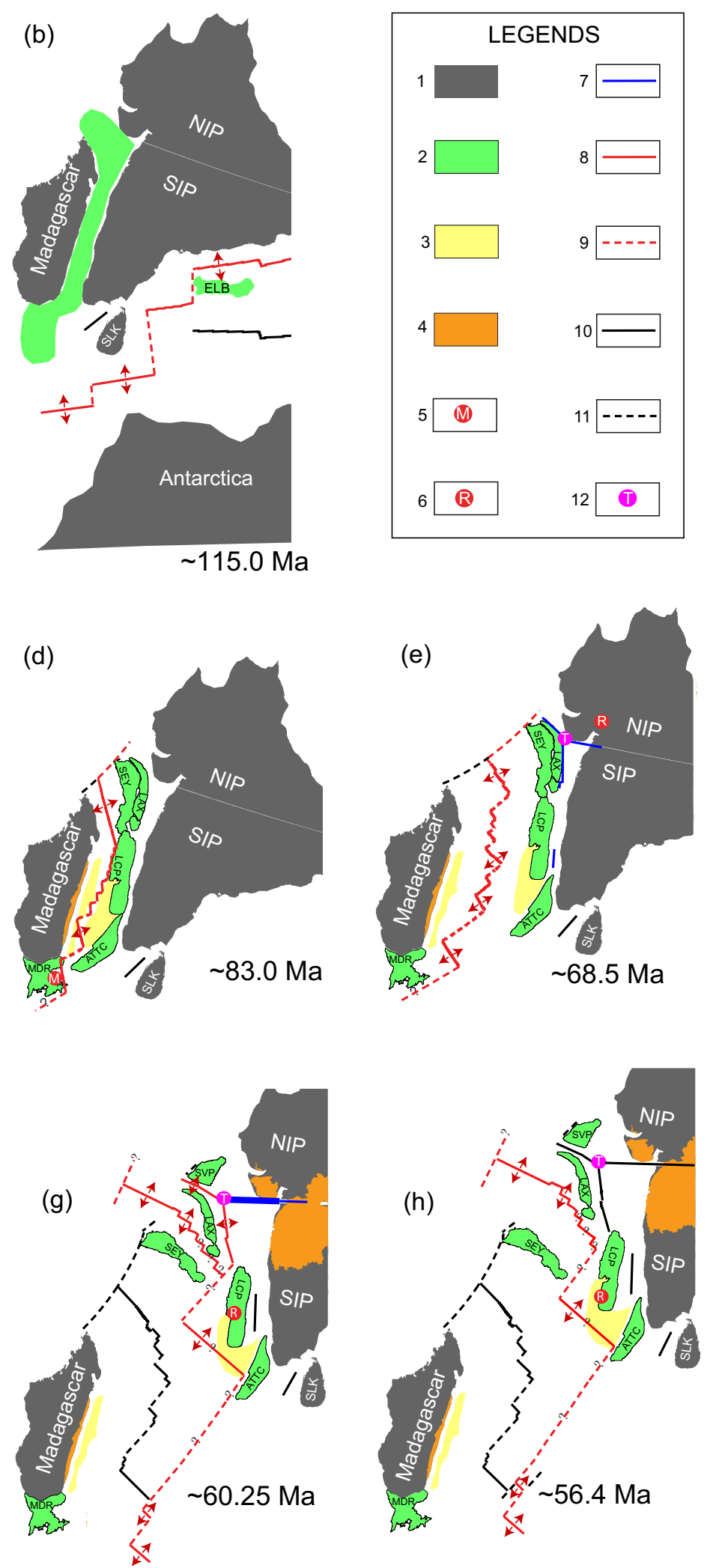

Figure 8. Schematic diagram depicting the major stages of breakup and formation of the continental margins of India and the adjacent ocean basins, based on Bhattacharya and Yatheesh (2015), Shuhail et al. (2018) and Gibbons et al. (2013). (a) 126.7 Ma; (b) 115.0 Ma; (c) $~ 88.0 \mathrm{Ma}$; (d) 83.0 Ma; (e) 68.5 Ma; (f) 62.5 Ma; (g) 60.25 Ma; (h) $56.4 \mathrm{Ma}$. Explanations to the legend are as follows: (1) Major continental blocks, (2) Microcontinents/ continental crust that later broke up to form the microcontinents, (3) Ultra-thinned continental crust, (4) Volcanics, (5) Location of the Marion Hotspot, (6) location of the Rèunion Hotspot, (7) Rift axis, (8) Ridge axis, (9) Transform fault, (10) Extinct spreading centre / failed rift, (11) Palaeo-transform fault, (12) location of the Gop-Narmada-Laxmi fossil Triple Junction off the Saurashtra Peninsula. SIP: Southern Indian Protocontinent; NIP: Northern Indian Protocontinent; SLK: Sri Lanka. Other details are as in Figures 1 and 4. 
side. The constraint to this age comes from the age of the oldest magnetic lineations representing chron M12n (132 Ma) identified from these conjugate basins (Talwani et al., 2016). Subsequently, at around 126.7 Ma (Figure 8a), spreading was initiated between these blocks, creating oceanic crust in the Eastern Enderby Basin since chron M4 (126.7 Ma) and this situation continued till the spreading ceased in the Eastern Enderby Basin, at around 115 Ma (Gibbons et al., 2013). A divergence is believed to have occurred contemporaneously between India and Sri Lanka, creating the Mannar Basin, bringing Sri Lanka into its present position relative to India (Gibbons et al., 2013).

\section{(b) Separation of ANT-ELB and SLK blocks from SIP-NIP-LAX-LCP-SEY-MAD block:}

At around 115 Ma, seafloor spreading in the Eastern Enderby Basin and the crustal divergence in the Mannar Basin ceased and the spreading centre in the Eastern Enderby Basin jumped north of the Elan Bank initiating a new spreading centre between Elan Bank and India (Figure 8b). As a result, the Elan Bank and the Eastern Enderby Basin crust got welded with Antarctic Plate and Sri Lanka got welded to the Indian Plate. The seafloor spreading along this new spreading centre continued creating the conjugate flanks of the oceanic crust in the Eastern Basin of Bay of Bengal and the region north of Elan Bank.

\section{(c) Separation of SIP-NIP-SLK-LAX-LCP-SEY block from MAD block:}

The breakup of SIP-NIP-SLK-LAX-LCP-SEY block is believed to have been caused by the Marion Hotspot at around $90 \mathrm{Ma}$, as evidenced by the existence of 85-92 Ma volcanics on the western side of India (Valsangkar, 1981; Torsvik et al., 2000; Pande et al., 2001; Melluso et al., 2009; Ram Mohan et al., 2016; Sheth et al., 2017) and the eastern side of Madagascar (Storey et al., 1995; Torsvik et al., 2000). At around $88 \mathrm{Ma}$, a rift was initiated between Madagascar and SIP-NIP-SLK-LAX-LCP-SEY block (Figure 8c) and following this, a strike-slip motion occurred between southeast coast of Madagascar and southwest coast of India, resulting in the formation of the Chain-Kairali Escarpment (Bhattacharya and Yatheesh, 2015; Shuhail et al., 2018). This motion also resulted in a configuration where the Alleppey-Trivandrum Terrace Complex broke away from Madagascar side forming a bathymetric notch in the Northern Madagascar Ridge. This was followed by seafloor spreading accreting oceanic crust in the Mascarene Basin (Figure 8d).

\section{(d) Formation and evolution of the GNL Triple Junction and the Laccadive Basin:}

At $\sim 68.5 \mathrm{Ma}$, the Gop-Narmada-Laxmi (GNL) Triple Junction was initiated off Saurashtra, with three rift axes. Subsequently this created the Laxmi Basin, Gop Basin and the Narmada Rift Graben (Bhattacharya and Yatheesh, 2015), dividing India into the Northern Indian Protocontinent and the Southern Indian Protocontinent (Figure 8e). Rift-drift transition occurred in the Laxmi and Gop basins at chrons C30n and C29r, respectively. During this period, another rift axis also existed in the region between the southwestern part of India and the Laccadive Plateau, creating the Laccadive Basin. At around 62.5 Ma, a new spreading axis was initiated between Seychelles and the Laxmi Ridge, creating the conjugate Arabian and Eastern Somali basins (Figure 8f). However, the divergence in the Laxmi, Gop, Laccadive and Southern Mascarene basins continued further and sometime around 60.25 Ma, the divergence in the Southern Mascarene and Laccadive basins ceased (Figure 8g). As a result, the Laccadive Plateau and the Laccadive Basin got attached to the Indian Plate, while the Southern Mascarene Basin got welded to Madagascar. Subsequently, at around 56.4 Ma, the axes of divergence in the Gop Basin, Laxmi Basin and the Narmada Rift also became extinct and all these basins got welded to the Indian Plate (Figure 8h). Seafloor spreading continued along the Carlsberg Ridge accreting oceanic crust in the conjugate Arabian and Eastern Somali basins in the Western Indian Ocean.

The above scenario suggests that the development of the northwestern continental margin of India was controlled to a great extent by the evolution of the Laxmi and Gop basins, while the development of the southwestern continental margin was controlled by the evolution of the Laccadive Basin and the easternmost part of the Southern Mascarene Basin. Thus, contrary to the conventional concept, it would appear that the conjugate of northwestern continental margin of India is the eastern flank of the Laxmi Ridge, while the conjugate of southwestern continental margin of India lies partly on the eastern flank of the Laccadive Plateau and partly on the eastern flank of the Northern Madagascar Ridge. This would also imply that the genesis of the structural features identified in the northwestern continental margin of India might be related to the breakup between India and welded Seychelles-Laxmi Ridge block, while those in the southwestern continental margin of India might be related to the breakup among India, Laccadive Plateau and the southeasternmost part of Madagascar.

\section{Some unresolved problems}

The breakup of the East Gondwanaland resulted in the formation of the continental margins and the adjacent deep offshore regions of the Indian Ocean. Geoscientific investigations carried out prior to the 1990s have provided a broad understanding on the structure and tectonics of the Indian Ocean as a whole. Subsequently, newer techniques and newly acquired closely-spaced data have built up on the earlier studies, facilitating a better understanding of the history of the Indian Ocean basin and the bordering continental margins. At the same time however, the new information has also thrown up many challenging questions related to the evolutionary history of the Indian Ocean that need to be addressed for a more comprehensive picture to emerge. Some of these questions are detailed in this section.

\section{Existence and extent of the Prathap and Kori- Comorin ridges}

The Prathap Ridge and the Kori-Comorin Ridge are the two structural features reported to be present in the western continental margin of India by Naini (1980) and Biswas and Singh (1988), respectively (Figure 9a,b). Naini (1980) identified isolated topographic highs between $2500 \mathrm{~m}$ and $3000 \mathrm{~m}$ isobaths on the continental slope and rise, between Cochin and Goa, and considered them as continuous sub-bottom highs forming an unbroken structural high between $7^{\circ} \mathrm{N}$ and $15^{\circ} \mathrm{N}$ latitudes, which he referred to as the Prathap Ridge. Subsequently, Biswas and Singh (1988) proposed the existence of a very prominent NW-SE trending linear fault-bounded 

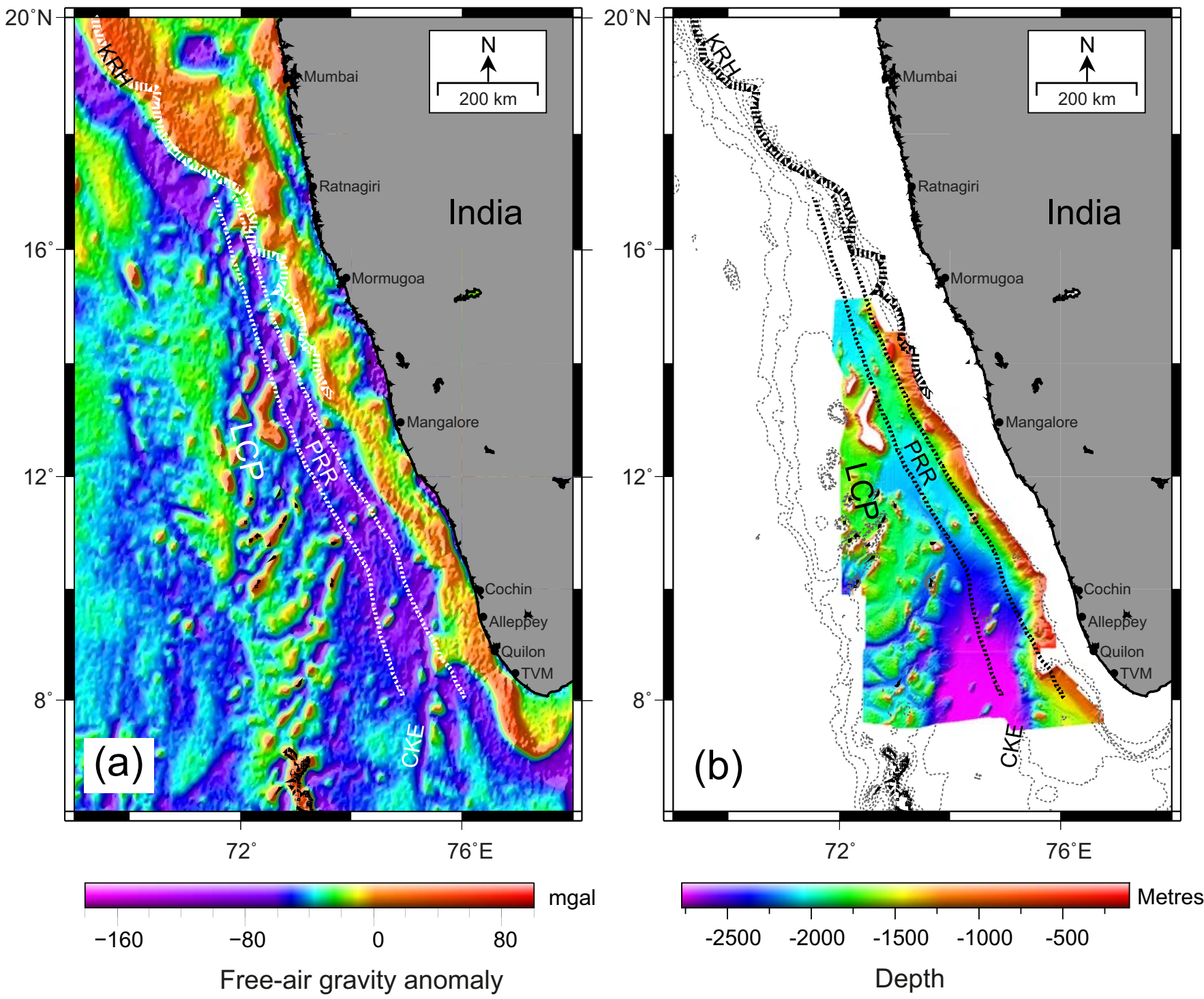

Figure 9. Maps showing the locations and postulated extents of the Prathap and Kori-Comorin ridges superimposed over: (a) satellitederived free-air gravity anomalies (Sandwell et al., 2014) and (b) multibeam bathymetry (Bijesh et al., 2018). PRR: Prathap Ridge; KRH: Kori High. Other details are as in Figure 4.

continuous structural high extending from Kutch shelf to Cape Comorin, termed as the Kori-Comorin Ridge, consisting of the Kori High in the north and the Prathap Ridge in the south. Other workers attempted to refine the extent of the Prathap Ridge with the help of additional regional seismic reflection, gravity and magnetic data and reported that the Prathap ridge is characterized by magnetic and gravity highs discernible on the ship track data. However, the latest available satellite-derived free-air gravity anomalies (Figure 9a) do not suggest the existence of such a prominent linear gravity high of $\sim 1000 \mathrm{~km}$ extent coinciding with the postulated location of the Prathap Ridge. Instead, the free-air gravity map shows the existence of several isolated gravity highs representing isolated structural highs. The multibeam bathymetry map of this region (Figure 9b) also suggests the existence of several isolated bathymetry highs, classified to represent seamounts, plateaus, hills, knolls and guyots (Bijesh et al., 2018). It is important to note that the continuity of the sub bottom structural highs representing the existence of Prathap Ridge for a distance of $~ 1000$ $\mathrm{km}$ was inferred based on the single channel seismic reflection data along sparsely distributed profiles, especially in the region between $7^{\circ} \mathrm{N}$ and $13^{\circ} \mathrm{N}$ latitudes. Therefore, a detailed revisit to the western continental margin of India using the closely spaced and high resolution gravity, magnetic and multichannel seismic reflection data is necessary to evaluate whether the structural highs identified by Naini (1980) represent isolated highs or they form part of a continuous subsurface ridge. This will also help to delineate the extent of the Kori-Comorin Ridge, which has been postulated to extend from the Kutch shelf to Cape Comorin.

\section{Location of the continent-ocean boundaries around the continental margins of India}

The nature and location of the boundary between the continental and oceanic crust in a passive continental margin setup is important to understand the processes related to rifting and the onset of seafloor spreading at a divergent plate boundary. Delineation of the continentocean boundary based only on the geophysical data appears to be 
elusive; however, the seaward dipping reflectors (SDRs) in seismic sections are considered to represent the locations of the continentocean boundary (COB) (Hinz, 1981; Mutter, 1985). As regards the Indian continental margins, the continent-ocean boundary in the eastern continental margin has been defined fairly well, and it is agreed upon that in general, the continent-ocean boundary lies along the foot of the continental slope, at a distance of $\sim 40 \mathrm{~km}$ from the coast. However, to date, there has been no consensus on the continentocean boundary in the western continental margin of India, probably due to the tectonic complexities of the region and paucity of adequate data.

Some authors (Krishna et al., 2006; Ajay et al., 2010) consider that the COB is located west of the Laxmi Ridge in the northern sector and west of the Laccadive Plateau in the southern sector of the western continental margin of India, by considering the existence of seaward dipping reflectors west of these features. Based on this demarcated COB, integrated with the crustal structure derived based on forward modelling of gravity data, they considered the entire wide swath of deep ocean basins located east of this inferred COB, consisting of the Gop, Laxmi and Laccadive basins to represent thinned continental crust. However, later studies (Corfield et al., 2010; Siawal et al., 2014; Misra et al., 2015) identified SDRs on both the flanks of the NW-SE trending segment of the Laxmi Ridge and the continental slope, implying oceanic nature of crust underlying the Laxmi Basin and the existence of three continent-ocean boundaries in the northwestern continental margin of India and the adjoining regions. In this scenario, the SDRs located in the western flank of the Laxmi Ridge represents the COB between the continental crust of the Laxmi Ridge and the oceanic crust of the Arabian Basin; the SDRs located in the eastern flank of the Laxmi Ridge represents the COB between the continental crust of the Laxmi Ridge and the oceanic crust of the Laxmi Basin; and the SDRs in the continental slope of India represents the COB between continental crust of India and the oceanic crust of the Laxmi Basin. Such an inference is further supported by the existence of seafloor spreading type magnetic lineations in the Laxmi Basin (Bhattacharya et al., 1994a; Yatheesh, 2007; Bhattacharya and Yatheesh, 2015) and the recovery of basalt from the basement retrieved by drilling in the Laxmi Basin during International Ocean Discovery Program Expedition 355 (Pandey et al., 2016).

Recently-published multichannel seismic reflection sections across the E-W trending segment of the Laxmi Ridge, Gop Basin and the Saurashtra Volcanic Platform clearly depict the existence of SDRs south of the Laxmi ridge (Collier et al., 2004; Misra et al., 2015) representing the COB between the Ridge and the oceanic crust in the Arabian Basin; and a separate sequence of SDRs south of the Saurashtra Volcanic Platform (Gaedicke et al., 2002; Calvès et al., 2011) representing the COB between the continental crust of Saurashtra Volcanic Platform and the oceanic crust of the Gop Basin. Such an existence of two COBs in the India/Pakistan continental margin is further supported by the presence of seafloor spreading magnetic lineations in the Gop Basin (Malod et al., 1997; Yatheesh, 2007; Collier et al., 2008; Yatheesh et al., 2009; Bhattacharya and Yatheesh, 2015). However, the COB representing the boundary between the continental crust of the Laxmi Ridge and the oceanic crust of the Gop Basin is yet to be imaged from seismic sections.

In the southern sector of the western continental margin of India, the COB has been inferred to be located west of the Laccadive Plateau, based on the location of SDRs and the nature of crust underlying the Laccadive Basin inferred by forward modelling of gravity anomalies. However, a wide swath of crust representing the Laccadive Basin exist east of this inferred COB. Unlike in the deep offshore regions representing the Laxmi and Gop basins, no seafloor spreading type magnetic lineations have been reported from the Laccadive Basin. However, such a scenario of lack of inferred magnetic lineations cannot be considered as the evidence to the "absence" of such seafloor spreading type magnetic lineations in the Laccadive Basin, since a detailed magnetic investigation using closely spaced magnetic data has not yet been undertaken in the Laccadive Basin, probably due to the unavailability of the adequate data. In addition, no high-resolution and deep penetrated multichannel seismic reflection sections are available in public domain to carry out detailed analysis to derive the crustal configuration and examine the possibility of existence of SDRs within the Laccadive Basin, and to find out their location if this region is underlain by oceanic crust. Moreover, there is no seismic velocitydepth information derived from seismic refraction data available from the Laccadive Basin to infer the detailed crustal structure as well as to use those information as a dependable constraint for the forward modeling of gravity anomalies. Therefore, the current status of the knowledge about the Laccadive Basin warrants a detailed integrated geophysical investigation based on seismic refraction experiment integrated with high resolution seismic reflection, gravity and magnetic data acquired over closely spaced profiles.

The Mannar Basin appears to have been formed by the crustal divergence between southeasternmost part of India and Sri Lanka. Based on the presence of igneous crust under the sediments, this deep ocean basin was originally considered to have underlain by oceanic crust. Followed by this, Baillie et al. (2002) inferred the existence of sediments beyond this igneous crust and this inference was considered against for the oceanic crust hypothesis in the Mannar Basin. Subsequent studies considered that the Mannar Basin is underlain by thinned continental crust with elevated Moho, representing a failed rift dominated with igneous activities causing emplacement of volcanics interbedded in the sediments. So far, no seafloor spreading magnetic lineations were reported in the Mannar Basin. However, one cannot negate the possibility of existence of oceanic crust overlain by thick pile of sediments in the Mannar Basin, based on the above observations. Therefore, as in the case of Laccadive Basin, a revisit to the Mannar Basin using the high-resolution seismic reflection and refraction, gravity and magnetic data will be useful to derive crustal configuration and to obtain the most reasonable explanation for the nature of crust underlying the Mannar Basin. If in case the Mannar Basin is underlain by oceanic crust, such a scenario will necessitate defining continent ocean boundary in the southeastern part of India and the western part of Sri Lanka.

\section{Timing of formation of the Laxmi, Gop, Laccadive and Mannar basins}

Timing of formation of ocean basins created at various divergent axes in the Indian Ocean are important to understand the spatiotemporal evolution of the Indian Ocean as a whole. These timings are well established for the ocean basins located far away from the continental margins, however, there exists several smaller ocean basins closer to the continental margins of India, whose nature of the underlying crust as well as the timing of formation is not well established. Some of these basins were formed by rifting only 
representing a failed rift, while others were formed by rifting followed by spreading representing extinct spreading centres. There are no direct methods to understand the timing of opening of an ocean basin formed by rifting alone using the geophysical data. However, the linear magnetic anomalies imprinted on the oceanic crust formed at a nowextinct spreading centre can provide important constraints on the age of the underlying oceanic crust and thereby the timing of opening and cessation of seafloor spreading in those ocean basins.

The Laxmi and Gop basins contain linear magnetic anomalies representing seafloor spreading between India/Pakistan margin and the Seychelles-Laxmi Ridge block. Correlation of the linear magnetic anomalies with geomagnetic timescale provides unique age estimate of the oceanic crust in the wide ocean basins containing larger linear magnetic anomaly sequences. But the magnetic lineations in the Gop and Laxmi basins are short and therefore a unique identification appears to be difficult. As a result, researchers proposed different age estimates ranging between chrons C33n and C29n for the opening and chrons C31r to C25r for cessation of the Gop and Laxmi basins. In case of the Laccadive and Mannar basins, no seafloor spreading type linear magnetic anomalies were reported so far and therefore no age constraints are available from geophysical data to define the timing of opening and cessation of divergence in these basins. As rightly pointed out by Bhattacharya and Yatheesh (2015), until the unambiguous age constraints are obtained from the Gop, Laxmi, Laccadive and Mannar basins, the plate tectonic evolution of the continental margins of India and the adjacent deep offshore regions cannot be established conclusively in proper temporal framework.

\section{Crustal structure, genesis and trend of the $85^{\circ} \mathrm{E}$ Ridge}

The $85^{\circ} \mathrm{E}$ Ridge is an important structural feature, represented as a basement high buried under the sediments, in the Bay of Bengal. This aseismic ridge has got attention of several researchers in the recent past and those studies (Bastia et al., 2010; Michael and Krishna, 2011; Sreejith et al., 2011; Rao and Radhakrishna, 2014; Ismaiel et al., 2017) provided important insights about the geophysical signatures, internal structure, extent and probable genesis of the $85^{\circ} \mathrm{E}$ Ridge. The extent of this anomalous basement high feature has been considered to start from Mahanadi Basin in the north to the AfanasyNikitin Seamount in the south. Several authors considered the genesis of the entire length of this basement high to represent volcanic trace from the same hotspot, while a recent study (Krishna et al., 2014) considered that the $85^{\circ} \mathrm{E}$ Ridge and the Afanasy-Nikitin Seamount are unrelated features arose from different mantle sources and the proximity of the southern end of the $85^{\circ} \mathrm{E}$ Ridge to the AfanasyNikitin Seamount is coincidental. The extent of the $85^{\circ} \mathrm{E}$ Ridge north of $6^{\circ} \mathrm{N}$ and south of $2^{\circ} \mathrm{N}$ trends in nearly $\mathrm{N}-\mathrm{S}$ direction, but it shows a major curvature between $2^{\circ} \mathrm{N}$ and $6^{\circ} \mathrm{N}$. If the $85^{\circ} \mathrm{E}$ Ridge is formed by the hotspot volcanism, such a change in direction implies a major reorientation of Indian plate motion during the time of formation of this segment of the $85^{\circ} \mathrm{E}$ Ridge. However, such a motion of the Indian plate has not been recorded in any other ocean basins / aseismic ridges in the Indian Ocean and therefore this observation warrants a satisfactory answer for considering a hotspot origin for the entire length of the $85^{\circ} \mathrm{E}$ Ridge.

Another important aspect of the $85^{\circ} \mathrm{E}$ Ridge is to understand the deep crustal architecture of the $85^{\circ} \mathrm{E}$ Ridge and the adjacent ocean basins. Ismaiel et al. (2017) derived the internal structure of the $85^{\circ} \mathrm{E}$ Ridge by identifying the volcanic successions and inferred that the $85^{\circ} \mathrm{E}$ Ridge is a volcanic construct built by both subaqueous and multiphase submarine volcanisms. Though the internal structure has been mapped in detail, the deeper structure of the $85^{\circ} \mathrm{E}$ Ridge awaits to be firmly established. A detailed seismic refraction experiment over this feature using the Ocean Bottom Seismometers will provide important constraints for such an understanding of the deeper crust over which the $85^{\circ} \mathrm{E}$ Ridge volcanics appears to have emplaced. In addition, the velocity-depth information derived from those seismic experiments can also evaluate the concept of existence of high density metasediments on either side of the $85^{\circ} \mathrm{E}$ Ridge and a broader Moho depression that are considered to cause the characteristic gravity low associated with this enigmatic feature.

\section{Establishing the nature and extent of the postulated microcontinental slivers in the Indian Ocean}

The Indian Ocean contains large number of aseismic ridges and submarine plateaus, whose origin are broadly attributed to the hotspot volcanism. However, the detailed investigations (Naini and Talwani, 1982; Plummer and Belle, 1995; Talwani and Reif, 1998; Nicolaysen et al., 2001; Borissova et al., 2003; Collier et al., 2009; Calvès et al., 2011; Bhattacharya and Yatheesh, 2015) carried out over those features reported strong evidences to consider some of those features, in part or full, to represent microcontinents. The broadly agreed major postulated microcontinents existing in the Indian Ocean are the Laxmi Ridge, Laccadive Plateau, Saurashtra Volcanic Platform, Seychelles Plateau, Northern Madagascar Ridge and the Elan Bank. In a recent study, Torsvik et al. (2013) proposed the existence of a Precambrian microcontinent, namely "Mauritia", which mainly consists of Mauritius Island and the continental fragments from the Southern Mascarene Plateau (e.g. parts of Saya de Malha, Nazareth and Cargados-Carajos banks) and the Laccadive, Maldive and Chagos areas adjacent to Indian margin. Subsequently, Bhattacharya and Yatheesh (2015) critically examined all the available information on the postulated microcontinents and attempted to provide a plate tectonic evolution model for the Western Indian Ocean by considering only those microcontinents whose continental affinity was betterconstrained. In their model, they accommodated the postulated continental blocks of the Laxmi Ridge, Seychelles Plateau, Laccadive Plateau and the Saurashtra Volcanic Platform as intervening continental slivers between India and Madagascar in their immediate pre-drift tectonic scenario. This model strongly suggests the existence of the above microcontinents, however, their crustal structure and the extent of the continental crust are yet to be confidently established. To decipher the plate tectonic evolution of the Indian Ocean, it is important to establish their continental nature and delineate the respective continent-ocean boundaries of all these postulated microcontinents since those COBs are the most representative boundary to obtain accurate plate reconstruction models. Therefore, the current status of the knowledge about the nature and extent of various postulated microcontinents necessitate confident establishment of their continental nature and the delineation of their extent by using high-resolution and deep penetrated multichannel seismic reflection data collected along closely spaced profiles, integrated with seismic refraction data, acquired using Ocean Bottom Seismometers. 


\section{The intense intraplate seismicity over Chagos Bank, a segment of an "aseismic" ridge}

The Chagos Bank represents the southernmost segment of the Laccadive-Chagos Ridge, which is considered as an aseismic ridge formed by Rèunion Hotspot volcanism in the past. The drilling at ODP Site 713, located in the northern part of the Chagos Bank, reached basaltic basement that yielded an age of 49 Ma (Duncan and Hargraves, 1990). The plate tectonic evolution models (McKenzie and Sclater, 1971; Norton and Sclater, 1979; Patriat and Segoufin, 1988) suggest that the Chagos and Saya de Malha banks were created contemporaneously by hotspot volcanism since $\sim 49 \mathrm{Ma}$, when the Rèunion Hotspot lay beneath or close to the spreading axis of the Central Indian Ridge. Subsequently, at 35 Ma, the Chagos Bank broke away from the Mascarene Plateau and a reorganization of the spreading centre occurred resulting in transferring of the Rèunion Hotspot to the African Plate and forming the younger parts of the Mascarene Plateau. This tectonic framework clearly shows that the Chagos Bank qualifies to be considered as a part of the aseismic ridge formed by past hotspot volcanism that is usually a region devoid of seismic activities. However, Stein (1978) reported an unusual, isolated earthquake swarm consisting of 16 events occurred during 1965-1970, over the steep west-facing scarp of the Chagos Bank. Based on the study of body and surface wave data of the three largest earthquakes, Stein (1978) opined that the swarm might have occurred at depth on a cross fracture remaining from the breakup of the Chagos Bank from the Mascarene Plateau and the formation of the present Central Indian Ridge. Based on the moment variance technique applied to the intraplate earthquakes occurred over the Chagos Bank, Wiens (1986) inferred a regional tectonic deformation extending northeast of Chagos Bank consisting of thrust, normal and strike-slip events, representing repeated reactivation of weak zones (presumably fracture zones) by a regional stress regime characterized by N-S extension with E-W and vertical compression. Based on the moment release computation using the detailed catalog of near-ridge earthquakes occurred between 1912 and 1993, Radhakrishna et al. (1998) suggested that the Chagos Bank seismicity forms part of the plate-wide stress distribution in the Central Indian Ocean. The earthquake data catalogue of International Seismological Centre (http:/ /www.isc.ac.uk/iscbulletin/search/catalogue) lists a total number of 209 earthquakes with magnitudes ranging from 3.4 to 6.7, occurred between 1965 and 2018, showing the continuing seismicity over the Chagos Bank.A passive seismic experiment using Ocean Bottom seismometers in this region would provide detailed velocity-depth constraints to derive the crustal structure of the Chagos Bank and the adjoining regions and thereby provide new insights on the cause of intraplate seismicity over the Chagos Bank segment of the LaccadiveChagos Ridge, which is considered as an aseismic ridge formed by past hotspot volcanism.

\section{Ways to go forward}

The marine geophysical investigations carried out in the Indian Ocean for the last four decades resolved several first order problems associated with structure and tectonics of the continental margins of India and the adjacent deep ocean basins. Most of these problems were addressed with the available sea-surface bathymetry, gravity, magnetic and the limited seismic reflection data, integrated with the sonobuoy refraction results of Naini (1980). Though considerable advancement in the understanding of these regions were achieved, there remains several important problems unresolved, which cannot be addressed solely with the existing sparse and conventional geophysical data.

Most of the unresolved problems described in the previous section can be addressed confidently by retrieving basement samples by deep sea drilling, however, it is not possible to ground truth everywhere in the ocean basins as it is too expensive. In absence of such ground truth data, it necessitates acquisition of high-resolution and deep penetrated multichannel seismic reflection data along closely spaced profiles as well as seismic refraction data using Ocean Bottom Seismometers, integrated with closely spaced gravity, magnetic and multibeam bathymetry data, that can provide important constraints to bridge those knowledge gaps. Acquisition and interpretation of the seismic refraction data over the regions such as the Laccadive Basin, $85^{\circ} \mathrm{E}$ Ridge, Mannar Basin, Chagos Bank and the several postulated microcontinents, can provide detailed velocity-depth information that can be used to infer the nature of crust underlying those regions and their detailed crustal structure. Similarly, acquisition and interpretation of high-resolution and deep penetrated multichannel seismic reflection data in the western continental margin of India and the adjacent ocean basins can be used to identify the possible seaward dipping reflectors and thereby delineate the continent-ocean boundary around Indian continental margins as well as the postulated microcontinents. These multichannel seismic reflection data along closely spaced profiles can also be used to identify the structures considered to represent the Prathap Ridge, examine the continuity of this feature from profile to profile and to map its linear as well as lateral extents.A passive seismic experiment using Ocean Bottom Seismometers conducted over the Chagos Bank and the adjoining regions can provideimportant insights on the cause of the recurring intraplate seismicity in this region. Acquisition and interpretation of magnetic data along closely spaced profiles in the Laccadive and Mannar basins will provide an opportunity to examine the possibility of existence of seafloor spreading type linear magnetic anomalies in these ocean basins. If any such linear magnetic anomalies are identified, correlation of them with the geomagnetic polarity reversal timescale can provide age constraints on the formation and cessation of these ocean basin. As explained earlier, the sea-surface magnetic data do not allow to derive a unique age corresponding to the magnetic anomalies observed in the Gop and Laxmi basins. An alternate approach for getting a better age constraint from these basins perhaps would be to use high resolution magnetic data collected by deep tow magnetic system that can provide characteristic signatures of the magnetic anomalies to aid their identification.

\section{Acknowledgement}

The author is grateful to Sunil Kumar Singh, Director, CSIRNational Institute of Oceanography (CSIR-NIO), Goa, India, for permission to publish this paper. I am thankful to K.A. Kamesh Raju for his constructive review and valuable suggestions that helped to improve the paper. I thank G.C. Bhattacharya for useful discussions; S. Rajan and Rasik Ravindra for their invitation to submit this paper to the $36^{\text {th }}$ IGC Special Issue of Episodes. All figures were drafted with the GMT software (Wessel and Smith, 1995). This is NIO contribution 6373. 


\section{References}

Ajay, K.K., Chaubey, A.K., Krishna, K.S., Gopala Rao, D. and Sar, D., 2010, Seaward dipping reflectors along the SW continental margin of India: Evidence for volcanic passive margin. Journal of Earth System Science, v. 119, pp. 803-813.

Alam, M., Alam, M.M., Curray, J.R., Chowdhury, M.L.R. and Gani, M.R., 2003, An overview of the sedimentary geology of the Bengal Basin in relation to the regional tectonic framework and basinfill history. Sedimentary Geology, v. 155, pp. 179-208.

Anand, S.P., Rajaram, M., Majumdar, T.J. and Bhattacharyya, R., 2009, Structure and Tectonics of $85^{\circ} \mathrm{E}$ Ridge from analysis of Geopotential data. Tectonophysics, v. 478, pp. 100-110.

Avraham, Z.B. and Bunce, E.T., 1977, Geophysical study of the Chagos-Laccadive Ridge, Indian Ocean. Journal of Geophysical Research, v. 82, pp. 1295-1305.

Baillie, P.W., Shaw, R.D., Liyanaarachchi, D.T.P. and Jayaratne, M.G., 2002, A New Mesozoic Sedimentary Basin, Offshore Sri Lanka. EAGE 64th Conference \& Exhibition Florence, Italy.

Baker, B.H. and Miller, J.A., 1963, Geology and geochronology of the Seychelles Islands and structure of the floor of the Arabian Sea. Nature, v. 199, pp. 346-348.

Bastia, R., 2006, An overview of Indian sedimentary basins with special focus on emerging east coast deepwater frontiers. The Leading Edge, v. 25, pp. 818-829.

Bastia, R. and Radhakrishna, M., 2012, Basin evolution and petroleum prospectivity of the continental margins of India. Elsevier Publications, UK,417 p.

Bastia, R., Radhakrishna, M., Das, S., Kale, A.S. and Catuneanu, O., 2010, Delineation of the 85 degrees E ridge and its structure in the Mahanadi Offshore Basin, Eastern Continental Margin of India (ECMI), from seismic reflection imaging. Marine and Petroleum Geology, v. 27, pp. 1841-1848.

Bernard, A. and Munschy, M., 2000, Le bassin des Mascareignes et le bassin de Laxmi (ocen Indien occidental) se sont-ils formes a I'axe d'un meme centre d'expansion? Comptes Rendus de I'Academie des Sciences - Series IIA - Earth and Planetary Science, v. 330, pp. 777-783.

Besse, J. and Courtillot, V., 1988, Paleogeographic maps of the continents bordering the Indian Ocean since the Early Jurassic. Journal of Geophysical Research, v. 93, pp. 11791-11808.

Bhattacharya, G.C. and Chaubey, A.K., 2001, Western Indian Ocean - A glimpse of the tectonic scenario. In: Sengupta, R. and Desa, E. (Eds.), The Indian Ocean - A Perspective. Oxford \& IBH Pub. Company Ltd., pp. 691-729.

Bhattacharya, G.C., Chaubey, A.K., Murty, G.P.S., Srinivas, K., Sarma, K.V.L.N.S., Subrahmanyam, V. and Krishna, K.S., 1994a, Evidence for seafloor spreading in the Laxmi Basin, northeastern Arabian Sea. Earth and Planetary Science Letters, v. 125, pp. 211-220.

Bhattacharya, G.C., Murty, G.P.S., Srinivas, K., Chaubey, A.K., Sudhakar, T. and Nair, R.R., 1994b, Swath bathymetric investigation of the seamounts located in Laxmi Basin, Eastern Arabian Sea. Marine Geodesy, v. 17, pp. 169-182.

Bhattacharya, G.C. and Subrahmanyam, V., 1986, Extension of the Narmada-Son lineament on the continental margin off Saurashtra, Western India, as obtained from magnetic measurements. Marine Geophysical Researches, v. 8, pp. 329-344.

Bhattacharya, G.C. and Subrahmanyam, V., 1991, Geophysical study of a seamount located on the continental margin of India. GeoMarine Letters, v. 11, pp. 71-78.

Bhattacharya, G.C. and Yatheesh, V., 2015, Plate-tectonic evolution of the deep ocean basins adjoining the western continental margin of India - a proposed model for the early opening scenario. In: Mukherjee, S. (Ed.), Petroleum Geoscience: Indian Contexts. Springer International Publishing, Switzerland, pp. 1-61.

Bijesh, C.M., John Kurian, P., Yatheesh, V., Tyagi, A. and Twinkle, D., 2018, Morphotectonic characteristics, distribution and probable genesis of bathymetric highs off southwest coast of India. Geomorphology, v. 315, pp. 33-44.

Bisen, M., Sriram, K. and Gupte, S.S., 2010, Structure and tectonics of deep-water Kutch-Saurashtra area, Western India. Proceedings of the 8th Biennial International Conference \& Exposition on Petroleum Geophysics, organized by the Society of Petroleum Geophysicists, India (SPG), Hyderabad, 1-3 February, 2010.

Biswas, S.K., 1982, Rift basins in western margin of India and their hydrocarbon prospects with special reference to Kutch Basin. American Association of Petroleum Geologists Bullettin, v. 66, pp. 1497-1513.

Biswas, S.K., 1987, Regional tectonic framework, structure and evolution of the western marginal basins of India. Tectonophysics, v. 135 , pp. 307-327.

Biswas, S.K., 1989, Hydrocarbon exploration in western offshore basins of India. Recent Geoscientific Studies in the Arabian Sea Off India. Geological Survey of India, Special Publication 24, pp. 185-194.

Biswas, S.K. and Singh, N.K., 1988, Western continental margin of India and hydrocarbon potential of deep-sea basins. 7th Offshore Southeast Asia Conference, pp. 170-181.

Borissova, I., Coffin, M.F., Charvis, P. and Operton, S., 2003, Structure and development of a microcontinent: Elan Bank in the southern Indian Ocean. Geochemistry Geophysics Geosystems, v. 4, doi:10.1029/2003GC000535.

Calvès, G., Schwab, A.M., Huuse, M., Clift, P.D., Gaina, C., Jolley, D., Tabrez, A.R. and Inam, A., 2011, Seismic volcanostratigraphy of the western Indian rifted margin: The pre Deccan igneous province. Journal of Geophysical Research, v. 116, doi:10.1029/ 2010JB000862.

Cande, S.C. and Kent, D.V., 1995, Revised calibration of the geomagnetic polarity time scale for the Late Cretaceous and Cenozoic. Journal of Geophysical Research, v. 100, pp. 60936095.

Cande, S.C. and Patriat, P., 2015, The anticorrelated velocities of Africa and India in the Late Cretaceous and early Cenozoic. Geophysical Journal International, v. 200, pp. 227-243.

Cande, S.C., Patriat, P. and Dyment, J., 2010, Motion between the Indian, Antarctic and African plates in the early Cenozoic. Geophysical Journal International, v. 183, pp. 127-149.

Chand, S., Radhakrishna, M. and Subrahmanyam, C., 2001, IndiaEast Antarctica conjugate margins: rift-shear tectonic setting inferred from gravity and bathymetry data. Earth and Planetary Science Letters, v. 185, pp. 225-236.

Chaubey, A.K., Bhattacharya, G.C., Murty, G.P.S., Srinivas, K., Ramprasad, T. and Rao, D.G., 1998, Early Tertiary seafloor spreading magnetic anomalies and paleo-propagators in the northern Arabian Sea. Earth and Planetary Science Letters, v. 154, pp. 41-52.

Chaubey, A.K., Dyment, J., Bhattacharya, G.C., Royer, J.Y., Srinivas, K. and Yatheesh, V., 2002a, Paleogene magnetic isochrons and palaeo-propagators in the Arabian and Eastern Somali basins, NW Indian Ocean. In: Clift, P.D., Croon, D., Gaedicke, C. and Craig, J. (Eds.), The Tectonic and Climatic Evolution of the Arabian Sea Region. Geological Society, London, Special Publication 195, pp. 71-85.

Chaubey, A.K., Rao, D.G., Srinivas, K., Ramprasad, T., Ramana, M.V. and Subrahmanyam, V., 2002b, Analyses of multichannel seismic 
reflection, gravity and magnetic data along a regional profile across the central-western continental margin of India. Marine Geology, v. 182, pp. 303-323.

Chaubey, A.K., Srinivas, K., Ashalatha, B. and Gopala Rao, D., 2008, Isostatic response of the Laccadive Ridge from admittance analysis of gravity and bathymetry data. Journal of Geodynamics, v. 46, pp. 10-20.

Coffin, M.F., Pringle, M.S., Duncan, R.A., Gladczencko, T.P., Storey, M., Müller, R.D. and Gahagan, L.M., 2002, Kerguelen hotspot magma output since 130 Ma. Journal of Petrology, v. 43, pp. 1121-1139.

Collier, J.S., Minshull, T.A., Hammond, J., Whitmarsh, R.B., Kendall, J.-M., Sansom, V., Lane, C.I. and Rumpker, G., 2009, Factors influencing magmatism during continental break-up: new insights from a wide-angle seismic experiment across the conjugate Seychelles-Indian margins. Journal of Geophysical Research, v. 114, B03101, doi:10.1029/2008JB005898.

Collier, J.S., Minshull, T.A., Kendall, J.-M., Whitmarsh, R.S., Rumpker, G., Joseph, P., Samson, P., Lane, C.I., Sansom, V., Vermeesch, P.M., Hammond, J., Wookey, J., Teanby, N., Ryberg, T. and Dean, S.M., 2004, Rapid Continental Breakup and Microcontinent Formation in the Western Indian Ocean. EOS Transactions American Geophysical Union, v. 85, pp. 481, 496.

Collier, J.S., Sansom, V., Ishizuka, O., Taylor, R.N., Minshull, T.A. and Whitmarsh, R.B., 2008, Age of Seychelles-India break-up. Earth and Planetary Science Letters, v. 272, pp. 264-277.

Corfield, R.I., Carmichael, S., Bennett, J., Akhter, S., Fatimi, M. and Craig, T., 2010, Variability in the crustal structure of the West Indian Continental Margin in the Northern Arabian Sea. Petroleum Geoscience, v. 16, pp. 257-265.

Curray, J.R. and Manasinghe, T., 1991, Origin of the Rajmahal Traps and the 85 East Ridge: Preliminary reconstructions of the trace of the Crozet hotspot. Geology, v. 19, pp. 1237-1240.

Das, P., Iyer, S., Kodagali, V.N. and Krishna, K.S., 2005, Distribution and Origin of Seamounts in the Central Indian Ocean Basin. Marine Geodesy, v. 28, pp. 259-269.

Deplus, C., Diament, M., Hebert, H., Bertrand, G., Dominguez, S., Dubois, J., Malod, J.A., Patriat, P., Pontoise, B. and Sibilla, J., 1998, Direct evidence of active deformation in the eastern Indian oceanic plate. Geology, v. 26, pp. 131-134.

Desa, M., Ramana, M.V. and Ramprasad, T., 2006, Seafloor spreading magnetic anomalies south off Sri Lanka. Marine Geology, v. 229, pp. 227-240.

DGH, 2018a, Directorate General of Hydrocarbons (DGH), Noida, India, web page: Cauvery Basin. http://www.dghindia.gov.in/ assets/downloads/56cfe94a4c105The_Cauvery_Basin.pdf. Accessed on 07 December 2018.

DGH, 2018b, Directorate General of Hydrocarbons (DGH), Noida, India, web page: Kerala-Konkan Basin. http://www.dghindia.gov. in/assets/downloads/56cfd920029d9The_KeralaKonkan_basin.pdf. Accessed on 17 December 2018.

Dietz, R.S. and Holden, J.C., 1970, Reconstruction of Pangea: breakup and dispersion of continents, Permian to present. Journal of Geophysical Research, v. 75, pp. 4939-4963.

Duncan, R.A., 1978, Geochronology of basalts from the Ninetyeast Ridge and continental dispersion in the Eastern Indian Ocean. Journal of Volcanology and Geothermal Research, v. 4, pp. 283305.

Duncan, R.A., 1990, The volcanic record of the Reunion hotspot. In: Duncan, R.A., Backman, J., Peterson, L.C., et al. (Ed.), Proceedings of ODP Scientific Results. Ocean Drilling Programme, College Station, TX, pp. 3-10.

Duncan, R.A. and Hargraves, R.B., 1990, ${ }^{40} \mathrm{Ar} /{ }^{39} \mathrm{Ar}$ Geochronology of basement rocks from the Mascarene Plateau, the Chagos Bank, and the Maldives Ridge. In: Duncan, R.A., Backman, J., Peterson, .C., et al. (Ed.), Proceedings of ODP Scientific Results. Ocean Drilling Programme, College Station, TX, pp. 43-51.

Dyment, J., 1991, Structure et évolution de la lithosphère océanique dans l'océan Indien: apport des anomalies magnétiques. Université Louis Pasteur. PhD Thesis, Université Louis Pasteur, Strasbourg, $374 \mathrm{p}$.

Dyment, J., 1993, Evolution of the Indian-Ocean Triple Junction between 65 and 49 Ma (Anomalies 28 to 21). Journal of Geophysical Research, v. 98, pp. 13863-13877.

Dyment, J., 1998, Evolution of the Carlsberg Ridge between 60 and $45 \mathrm{Ma}$ : ridge propagation, spreading asymmetry, and the DeccanReunion hotspot. Journal of Geophysical Research, v. 103, pp. 24067-24084.

Eagles, G. and Wibisono, A.D., 2013, Ridge push, mantle plumes and the speed of the Indian plate. Geophysical Journal International, v. 194, pp. 670-677.

Faruque, B.M., Vaz, G.G. and Mohapatra, G.P., 2014, The continental shelf of eastern India. Geological Society, London, Memoirs, v. 41, pp. 221-229.

Fisher, R.L., Sclater, J.G. and McKenzie, D.P., 1971, The evolution of the Central Indian Ridge, Western Indian Ocean. Geological Society of America Bulletin, v. 82, pp. 553-562.

Gaedicke, C., Schlutter, H.U., Roeser, H.A., Prexl, A., Schreckenberger, B., Meyer, H., Reichert, C., Clift, P. and Amjad, S., 2002, Origin of the Northern Indus Fan and Murray ridge, Northern Arabian Sea: Interpretation from seismic and magnetic imaging. Tectonophysics, v. 355, pp. 127-143.

Gaina, C., Müller, R.D., Brown, B., Ishihara, T. and Ivanov, S., 2007, Breakup and early seafloor spreading between India and Antarctica. Geophysical Journal International, v. 170, pp. 151169.

Gibbons, A.D., Whittaker, J.M. and Müller, R.D., 2013, The breakup of East Gondwana: Assimilating constraints from Cretaceous ocean basins around India into a best-fit tectonic model. Journal of Geophysical Research-Solid Earth, v. 118, pp. 808-822.

Gombos, A.M., Powell, W.G. and Norton, I.O., 1995, The tectonic evolution of western India and its impact on hydrocarbon occurrences - an overview. Sedimentary Geology, v. 96, pp. 119129.

Goslin, J., Recq, M. and Schlich, R., 1981, Structure profonde du plateau de Madagascar: relations avec le plateau de crozet. Tectonophysics, v. 76, pp. 75-97.

Goslin, J., Segoufin, J., Schlich, R. and Fisher, R.L., 1980, Submarine topography and shallow structure of the Madagascar Ridge, western Indian Ocean. Geological Society of America Bulletin, v. 91, pp. 741-753.

Gupta, S.K., 2006, Basin architecture and petroleum system of Krishna Godavari Basin, east coast of India. The Leading Edge, v. 25, pp. 830-837.

Herath, P., Gunatilake, J. and Weerasinghe, D., 2017, Mohorivicic discontinuity beneath Mannar Basin : A failed-rift. Journal of Geological Society of Sri Lanka, v. 18, pp. 77-87.

Hinz, K., 1981, Hypothesis on terrestrial catastrophes: wedges of very thick oceanward dipping layers beneath passive continental margins - their origins and paleoenvironmental significance. Geologisches Jahrbuch, v. E22, pp. 3-28.

Hossain, M.S., Khan, M.S.H., Chowdhury, K.R. and Abdullah, R., 2019, Synthesis of the Tectonic and Structural Elements of the Bengal Basin and Its Surroundings. In: Mukherjee, S. (Ed.), Tectonics and Structural Geology: Indian Context. Springer International Publishing, Switzerland, pp. 135-218.

IOC-IHO-BODC, 2003, Centenary Edition of the GEBCO Digital Atlas, published on CD-ROM on behalf of the Intergovernmental 
Oceanographic Commission and the International Hydrographic Organization as part of the General Bathymetric Chart of the Oceans. British Oceanographic Data Centre, Liverpool, UK.

Ismaiel, M., Krishna, K.S., Srinivas, K., Mishra, J. and Saha, D., 2017, Internal structure of the $85^{\circ} \mathrm{E}$ ridge, Bay of Bengal: Evidence for multiphase volcanism. Marine and Petroleum Geology, v. 80, pp. 254-264.

Jacob, J., Dyment, J. and Yatheesh, V., 2014, Revisiting the structure, age and evolution of the Wharton Basin to better understand subduction under Indonesia. Journal of Geophysical Research, v. 119, pp. 169-190.

Kahle, H.G., Naini, B.R., Talwani, M. and Eldholm, O., 1981, Marine geophysical study of the Comorin Ridge, North Central Indian Basin. Journal of Geophysical Research, v. 86, pp. 3807-3814.

Kamesh Raju, K.A., 1993, Magnetic lineations, fracture zones and seamounts in the Central Indian Basin. Marine Geology, v. 109, pp. 195-201.

Kamesh Raju, K.A. and Ramprasad, T., 1989, Magnetic lineations in the Central Indian Basin for the period A24-A21: a study in relation to the Indian Ocean Triple Junction trace. Earth and Planetary Science Letters, v. 95, pp. 395-402.

Khan, A.A. and Chouhan, R.K.S., 1996, The crustal dynamics and the tectonic trends in the Bengal Basin. Journal of Geodynamics, v. 22, pp. 267-286.

Kolla, V. and Coumes, F., 1990, Extension of structural and tectonic trends from the Indian subcontinent into the Eastern Arabian Sea. Marine and Petroleum Geology, v. 7, pp. 188-196.

Krishna, K.S., 2003, Structure and evolution of the Afanasy Nikitin seamount, buried hills and 85E Ridge in the northeastern Indian Ocean. Earth and Planetary Science Letters, v. 209, pp. 379-394.

Krishna, K.S., Abraham, H., Sager, W.W., Pringle, M.S., Frey, F., Gopala Rao, D. and Levchenko, O.V., 2012, Tectonics of the Ninetyeast Ridge derived from spreading records in adjacent oceanic basins and age constraints of the ridge. Journal of Geophysical Research, v. 117, doi: 10.1029/2011JB008805.

Krishna, K.S., Bull, J.M., Ishizuka, O., Scrutton, R.A., Jaishankar, S. and Banakar, V.K., 2014, Growth of the Afanasy Nikitin seamount and its relationship with the $85^{\circ} \mathrm{E}$ Ridge, northeastern Indian Ocean. Journal of Earth System Science, v. 123, pp. 3347.

Krishna, K.S., Bull, J.M. and Scrutton, R.A., 2001, Evidence for multiphase folding of the Central Indian Ocean lithosphere. Geology, v. 29, pp. 715-718.

Krishna, K.S., Michael, L., Bhattacharyya, R. and Majumdar, T.J., 2009, Geoid and gravity anomaly data of conjugate regions of Bay of Bengal and Enderby Basin: New constraints on breakup and early spreading history between India and Antarctica. Journal of Geophysical Research-Solid Earth, v. 114, doi: 10.1029/ 2008jb005808.

Krishna, K.S., Murty, G.P.S., Srinivas, K. and Rao, D.G., 1992, Magnetic Studies over the Northern Extension of the Prathap Ridge Complex, Eastern Arabian Sea. Geo-Marine Letters, v. 12, pp. 7-13.

Krishna, K.S., Rao, D.G., Ramana, M.V., Subrahmanyam, V., Sarma, K.V.L.N.S., Pilipenko, A.I., Shcherbakov, V.S. and Murthy, I.V.R., 1995, Tectonic model for the evolution of oceanic crust in the northeastern Indian Ocean from the Late Cretaceous to the Early Tertiary. Journal of Geophysical Research, v. 100, pp. 2001120024.

Krishna, K.S., Rao, D.G. and Sar, D., 2006, Nature of the crust in the Laxmi Basin $\left(14^{\circ}-20^{\circ}\right)$, western continental margin of India. Tectonics, v. 25, TC1006, doi:10.1029/2004TC001747.

Kumar, S.P., 1983, Geology and hydrocarbon prospects of KrishnaGodavari and Cauvery basins. In: Bhandari, L.L. (Ed.),
Petroliferous Basins of India, Petroleum Asia Journal 6 Himachal Times Group Publication, Dehradun, pp. 57-65.

Kunnummal, P., Anand, S.P., Haritha, C. and Rama Rao, P., 2018, Moho depth variations over the Maldive Ridge and adjoining Arabian and Central Indian Basins, Western Indian Ocean, from three dimensional inversion of gravity anomalies. Journal of Asian Earth Sciences, v. 156, pp. 316-330.

Lal, N.K., Siawal, A. and Kaul, A.K., 2009, Evolution of east coast of India - A plate tectonic reconstruction. Journal of the Geological Society of India, v. 73, pp. 249-260.

Liu, C.-S., Curray, J.R. and McDonald, J.M., 1983, New constraints on the tectonic evolution of the eastern Indian Ocean. Earth and Planetary Science Letters, v. 65, pp. 331-342.

Malod, J.A., Droz, L., Mustafa Kamal, B. and Patriat, P., 1997, Early spreading and continental to oceanic basement transition beneath the Indus-deep sea fan: northeastern Arabian Sea. Marine Geology, v. 141, pp. 221-235.

Mathur, R.B. and Nair, K.M., 1993, Exploration of Bombay Offshore Basin. In: Biswas, S.K., Dave, A., Garg, P., Pandey, J., Maithani, A. and Thomas, N.J. (Eds.), Proceedings of the Second Seminar on Petroliferous Basins of India. Indian Petroleum Publishers, Dehradun, pp. 365-396.

Mazumder, S., Pangtey, K.K.S. and Mitra, D.S., 2013, Delineation of a possible subsurface ridge in Onshore Palar Basin based on morphotectonic studies and its implications. 10th Biennial international conference \& exposition, Kochi, Society of Petroleum Geophysicists, pp. 1-6.

Mazumder, S., Tep, B., Pangtey, K.K.S. and Mitra, D.S., 2019, Basement Tectonics and Shear Zones in Cauvery Basin (India): Implications in Hydrocarbon Exploration. In: Mukherjee, S. (Ed.), Tectonics and Structural Geology: Indian Context. Springer International Publishing, Switzerland, pp. 279-311.

McKenzie, D. and Sclater, J.G., 1971, The evolution of the Indian Ocean since the Late Cretaceous. Geophysical Journal Royal Astronomical Society, v. 25, pp. 437-528.

Melluso, L., Sheth, H.C., Mahoney, J.J., Morra, V., Petrone, C.M. and Storey, M., 2009, Correlations between silicic volcanic rocks of the St. Mary's Islands (southwestern India) and eastern Madagascar : implications for Late Cretaceous India-Madagascar reconstructions. Journal of the Geological Society, London, v. 166, pp. 283-294.

Michael, L. and Krishna, K.S., 2011, Dating of the 85 degrees E Ridge (northeastern Indian Ocean) using marine magnetic anomalies. Current Science, v. 100, pp. 1314-1322.

Miles, P.R. and Roest, W.R., 1993, Earliest seafloor spreading magnetic anomalies in the north Arabian Sea and the oceancontinent transition. Geophysical Journal International, v. 115, pp. 1025-1031.

Minshull, T.A., Lane, C.I., Collier, J.S. and Whittmarsh, R.B., 2008, The relationship between rifting and magmatism in the northeastern Arabian Sea. Nature Geoscience, v. 1, pp. 463-467.

Mishra, A., Chaubey, A.K., Sreejith, K.M. and Kumar, S., 2018, Crustal underplating and effective elastic plate thickness of the Laxmi Ridge, northern Arabian Sea. Tectonophysics, v. 744, pp. 82-92.

Misra, A.A., Sinha, N. and Mukherjee, S., 2015, Repeat ridge jumps and microcontinent separation: insights from NE Arabian Sea. Marine and Petroleum Geology, v. 59, pp. 406-428.

Mohinuddin, S.K., Satyanarayana, K. and Rao, G.N., 1993, Cretaceous sedimentation in the subsurface of Krishna Godavari basin. Journal of the Geological Society of India, v. 41, pp. 533-539.

Murthy, K.S.R., Rao, T.C.S., Subrahmanyam, A.S., Malleswara Rao, M.M. and Lakshminarayana, S., 1993, Structural lineaments from the magnetic anomaly maps of the eastern continental margin of 
India (ECMI) and NW Bengal Fan. Marine Geology, v. 114, pp. 171-183.

Murthy, K.S.R., Subrahmanyam, A.S. and Subrahmanyam, V., 2012, Tectonics of the eastern continental margin of India. The Energy and Resources Institute (TERI), New Delhi, 181 p.

Murty, A.V.S., Arasu, R.T., Dhanawat, B.S. and Subrahmanyam, V.S.R., 1999, Some aspects of deepwater exploration in the light of new evidences in the western Indian offshore. Third International Petroleum conference and exhibition, PETROTECH, pp. 457-462.

Mutter, J.C., 1985, Seaward dipping reflectors and the continentocean boundary at passive continental margins. Tectonophysics, v. 114 , pp. 117-131.

Naini, B.R., 1980, Geological and Geophysical study of the continental margin of Western India, and the adjoining Arabian Sea including the Indus cone. $\mathrm{PhD}$ Thesis, Columbia University, $173 \mathrm{p}$.

Naini, B.R. and Talwani, M., 1982, Structural framework and the evolutionary history of the continental margin of Western India. In: Watkins, J.S. and Drake, C.L. (Eds.), Studies in continental margin geology. American Association of Petroleum Geologists, pp. 167-191.

Nair, N., Anand, S.P. and Rajaram, M., 2013, Tectonic framework of Laccadive Ridge in Western Continental Margin of India. Marine Geology, v. 346, pp. 79-90.

Nair, N., Anand, S.P., Rajaram, M. and Rao, P.R., 2015, A relook into the crustal architecture of Laxmi Ridge, northeastern Arabian Sea from geopotential data. Journal of Earth System Science, v. 124, pp. 613-630.

Nathaniel, D.M., 2013, Hydrocarbon Potential of Sub-Basalt Mesozoics of Deepwater Kerala Basin, India. 10th Biennial International Conference \& Exposition Kochi 2013, p. 1-7.

Nathaniel, D.M., Bastia, R., Tenepalli, S., Akella, M., Verma, R. and D'Silva, K., 2008, Mesozoics of the south western margin of India: A frontier exploration. 19th World Petroleum Congress, Spain, World Petroleum Council.

Nayak, G.K. and Rao, C.R., 2002, Structural Configuration of Mahanadi Offshore Basin, India: An Aeromagnetic Study. Marine Geophysical Researches, v. 23, pp. 471-479.

Nemcok, M., Sinha, S.T., Stuart, C.J., Welker, C., Choudhuri, M., Sharma, S.P., Misra, A.A., Sinha, N. and Venkatraman, S., 2013, East Indian margin evolution and crustal architecture: integration of deep reflection seismic interpretation and gravity modelling. Geological Society, London, Special Publications, v. 369, pp. 477 496.

Nicolaysen, K., Bowring, S., Frey, F., Weis, D., Ingle, S., Pringle, M.S. and Coffin, M.F., 2001, Provenance of Proterozoic garnetbiotite gneiss recovered from Elan Bank, Kerguelen Plateau, southern Indian Ocean. Geology, v. 29, pp. 235-238.

Norton, I.O. and Sclater, J.G., 1979, A model for the evolution of the Indian Ocean and the break-up of Gondwanaland. Journal of Geophysical Research, v. 84, pp. 6803-6830.

Pande, K., Sheth, H.C. and Bhutani, R., 2001, ${ }^{40} \mathrm{Ar}-{ }^{39} \mathrm{Ar}$ age of the St. Mary's Islands volcanics, southern India: record of India Madagascar break-up on the Indian subcontinent. Earth and Planetary Science Letters, v. 193, pp. 39-46.

Pande, K., Yatheesh, V. and Sheth, H., 2017, ${ }^{40} \mathrm{Ar} /{ }^{39} \mathrm{Ar}$ dating of the Mumbai tholeiites and Panvel flexure: intense 62.5 Ma onshoreoffshore Deccan magmatism during India-Laxmi RidgeSeychelles breakup. Geophysical Journal International, v. 210, pp. 1160-1170.

Pandey, D.K., Clift, P.D., Kulhanek, D.K. and Expedition 355 Scientists, 2016, Arabian Sea Monsoon, Proceedings of the International Ocean Discovery Program 355. International Ocean
Discovery Program, College Station, TX, doi:10.14379/ iodp.proc.355.2016.

Patriat, P. and Segoufin, J., 1988, Reconstruction of the Central Indian Ocean. Tectonophysics, v. 155, pp. 211-234.

Plummer, P.S. and Belle, E.R., 1995, Mesozoic tectono-stratigraphic evolution of the Seychelles microcontinent. Sedimentary Geology, v. 96, pp. 73-91.

Prabhakar, K.N. and Zutshi, P.L., 1993, Evolution of southern part of Indian east coast basins. Journal of the Geological Society of India, v. 41, pp. 215-230.

Prakash, R.S., Ramasamy, S. and Varghese, N.M., 2018, Provenance of the Gondwana sediments, Palar Basin, Southern India. Arabian Journal of Geosciences, v. 11:163, doi: 10.1007/s12517-0183494-6.

Premarathne, D.M.U.A.K., Suzuki, N., Ratnayake, N.P. and Kularathne, E.K.C.W., 2013, A Petroleum System in the Gulf of Mannar Basin, Offshore Sri Lanka. Proceedings to 29th Technical Sessions of Geological Society of Sri Lanka, pp. 9-12.

Radhakrishna, M., Srinivasa Rao, G., Satyabrata, N., Bastia, R. and Twinkle, D., 2012a, Early Cretaceous fracture zones in the Bay of Bengal and their tectonic implications: Constraints from multichannel seismic reflection and potential field data. Tectonophysics, v. 522-523, pp. 187-197.

Radha Krishna, M., Verma, R.K. and Arora, S.K., 1998, Near-ridge intraplate earthquakes in the Indian Ocean. Marine Geology, v. 147, pp. 109-122.

Radhakrishna, M., Twinkle, D., Nayak, S., Bastia, R. and Rao, S., 2012b, Crustal structure and rift architecture across the KrishnaGodavari basin in the central Eastern Continental Margin of India based on analysis of gravity and seismic data. Marine and Petroleum Geology, v. 37, pp. 129-146.

Rajaram, M., Anand, S.P. and Erram, V.C., 2000, Crustal Magnetic Studies over Krishna-Godavari Basin in Eastern Continental Margin of India. Gondwana Research, v. 3, pp. 385-393.

Ram Mohan, M.R., Shaji, E., Satyanarayanan, M., Santosh, M., Tsunogae, T., Yang, Q.-Y. and Dhanil Dev, S.G., 2016, The Ezhimala Igneous Complex, southern India: Possible imprint of Late Cretaceous magmatism within rift setting associated with India-Madagascar separation. Journal of Asian Earth Sciences, v. 121 , pp. 56-71.

Ramana, M.V., Desa, M.A. and Ramprasad, T., 2015, Reexamination of geophysical data off Northwest India: Implications to the Late Cretaceous plate tectonics between India and Africa. Marine Geology, v. 365, pp. 36-51.

Ramana, M.V., Nair, R.R., Sarma, K.V.L.N.S., Ramprasad, T., Krishna, K.S., Subrahmanyam, V., Paul, J., Subrahmanyam, A.S. and Chandrasekhar, D.V., 1994, Mesozoic anomalies in the Bay of Bengal. Earth and Planetary Science Letters, v. 121, pp. 469475.

Ramana, M.V., Rajendraprasad, B. and Hansen, R.D., 1987, Geophysical and geological surveys along the northeastern flank of Mount Error, Northwestern Indian Ocean. Marine Geology, v. 76, pp. 153-162.

Ramana, M.V., Ramprasad, T. and Desa, M., 2001, Seafloor spreading magnetic anomalies in the Enderby Basin, East Antarctica. Earth and Planetary Science Letters, v. 191, pp. 241-255.

Ramana, M.V., Subrahmanyam, V., Chaubey, A.K., Ramprasad, T., Sarma, K.V.L.N.S., Krishna, K.S., Desa, M. and Murty, G.P.S., 1997, Structure and origin of the $85^{\circ} \mathrm{E}$ Ridge. Journal of Geophysical Research, v. 102, pp. 17995-18012.

Ramaswamy, G. and Rao, K.L.N., 1980, Geology of the continental shelf of the west coast of India. In: Miall, A.D. (Ed.), Facts and Principles of Petroleum Occurrence. Canadian Society of Petroleum Geologists, Canada, pp. 801-821. 
Rao, G..N., 2001, Sedimentation, stratigraphy and petroleum potential of Krishna-Godavari Basin, east coast of India. American Association of Petroleum Geologists, v. 85, pp. 1623-1643.

Rao, D.G., Paropkari, A.L., Krishna, K.S., Chaubey, A.K., Ajay, K.K. and Kodagali, V.N., 2010, Bathymetric highs in the mid-slope region of the India - structure and mode of origin. Marine Geology, v. 276, pp. 58-70.

Rao, G.S., Kumar, M. and Radhakrishna, M., 2018, Structure, mechanical properties and evolution of the lithosphere below the northwest continental margin of India. International Journal of Earth Sciences, v. 107, pp. 2191-2207.

Rao, G.S. and Radhakrishna, M., 2014, Crustal structure and nature of emplacement of the $85^{\circ} \mathrm{E}$ Ridge in the Mahanadi offshore based on constrained potential field modeling: Implications for intraplate plume emplaced volcanism. Journal of Asian Earth Sciences, v. 85, pp. 80-96.

Rao, G.S., Radhakrishna, M., Sreejith, K.M., Krishna, K.S. and Bull, J.M., 2016, Lithosphere Structure and upper mantle characteristics below the Bay of Bengal. Geophysical Journal International, v. 206, pp. 675-695.

Royer, J.Y. and Gordon, R., 1997, The motion and boundary between the Capricon and Australian plates. Science, v. 277, pp. 12681276.

Royer, J.Y., Gordon, R.G., Demets, C. and Vogt, P.R., 1997, New limits on the motion between India and Australia since chron 5 (11 Ma) and implications for lithospheric deformation in the equatorial Indian Ocean. Geophysical Journal International, v. 129, pp. 41-74.

Royer, J.Y. and Schlich, R., 1988, Southeast Indian Ridge between the Rodrigues Tripple Junction and the Amsterdam and St. Pauls Islands: Detailed kinematics for the past 20 m.y. Journal of Geophysical Research, v. 93, pp. 13524-13550.

Sandwell, D.T., Müller, R.D., Smith, W.H.F., Garcia, E. and Francis, R., 2014, New global marine gravity model from CryoSat-2 and Jason-1 reveals buried tectonic structure. Science, v. 346, pp. 6567.

Sar, D., Maheshwari, M.K., Rangarajan, S. and Bahuguna, C.S., 2009, Eighty five degree east ridge and its hydrocarbon potential. Geohorizons, July 2009, pp. 15-23.

Sastri, V.V., Sinha, R.N., Singh, G. and Murti, K.V.S., 1973, Stratigraphy and tectonics of sedimentary basins on east coast of Peninsular India. American Association of Petroleum Geologists Bulletin, v. 57, pp. 655-678.

Sastri, V.V., Venkatachala, B.S. and Narayanan, V., 1981, The evolution of the east coast of India. Palaeogeography, Palaeoclimatology, Palaeoecology, v. 36, pp. 23-54.

Schlich, R., 1982, The Indian Ocean: aseismic Ridges, spreading centres and basins. In: Nairn, A.E.M. and Stehli, F.G. (Eds.), The Ocean Basins and Margins. Plenum Press, New York, pp. 51147.

Sclater, J.G. and Fisher, R.L., 1974, Evolution of the east-central Indian Ocean, with emphasis on the tectonic setting of the Ninetyeast Ridge. Geological Society of America Bullettin, v. 85, pp. 683702.

Sheth, H., Pande, K., Vijayan, A., Sharma, K.K. and Cucciniello, C., 2017, Recurrent Early Cretaceous, Indo-Madagascar (89-86 Ma) and Deccan (66 Ma) alkaline magmatism in the Sarnu-Dandali complex, Rajasthan: ${ }^{40} \mathrm{Ar} /{ }^{39} \mathrm{Ar}$ age evidence and geodynamic significance. Lithos, v. 284-285, pp. 512-524.

Sheth, H.C., 2005, From Deccan to Réunion: No trace of a mantle plume. In: Foulger, G.R., Natland, J.H., Presnall, D.C. and Anderson, D.L. (Eds.), Plates, Plumes, and Paradigms. Geological Society of America pp. 477-501.

Shuhail, M., Yatheesh, V., Bhattacharya, G.C., Müller, R.D., Kamesh
Raju, K.A. and Mahender, K., 2018, Formation and evolution of the Chain-Kairali Escarpment and the Vishnu Fracture Zone in the Western Indian Ocean. Journal of Asian Earth Sciences, v. 164, pp. 307-321.

Siawal, A., Samal, J.K. and Kaul, A.K., 2014, A note on identification of SDRs in Laxmi Basin of Arabian Sea region. ONGC Bulletin, v. 49, pp. 45-50.

Singh, N.K. and Lal, N.K., 1993, Geology and petroleum prospects of Konkan-Kerala Basin. In: Biswas, S.K., Dave, A., Garg, P., Pandey, J., Maithani, A. and Thomas, N.J. (Eds.), Proceedings of the Second Seminar on Petroliferous Basins of India. Indian Petroleum Publishers, Dehradun, pp. 461-469.

Smith, W.H.F. and Sandwell, D.T., 1997, Global sea floor topography from satellite altimetry and ship depth soundings. Science, v. 277, pp. 1956-1962.

Smith, W.H.F. and Sandwell, D.T., 2014, Global Topography V17.1., web page: ftp://topex.ucsd.edu/pub/global_topo_1min/.Accessed on 11 December 2018.

Sreejith, K., Radhakrishna, M., Krishna, K.S. and Majumdar, T.J., 2011, Development of the negative gravity anomaly of the $85^{\circ} \mathrm{E}$ Ridge, northeastern Indian Ocean - a process oriented modelling approach. Journal of Earth System Science, v. 120, pp. 605-615.

Sreejith, K.M., Krishna, K.S. and Bansal, A.R., 2008, Structure and isostatic compensation of the Comorin Ridge, northcentral Indian Ocean. Geophysical Journal International, v. 175, pp. 729-741.

Sreejith, K.M., Rajesh, S., Majumdar, T.J., Rao, G.S., Radhakrishna, M., Krishna, K.S. and Rajawat, A.S., 2013, High-resolution residual geoid and gravity anomaly data of the northern Indian Ocean - an input to geological understanding. Journal of Asian Earth Science, v. 62, pp. 616-626.

Sriram, K., Gupte, S.S., Kothari, V., Bisen, M. and Waraich, R.S., 2006, Structure and evolution of Saurashtra Arch in KutchSaurashtra deepwater area, Western India. 6th International Conference \& Exposition on Petroleum Geophysics, Kolkata, p. 21-25.

Storey, M., Mahoney, J.J., Saunders, A.D., Duncan, R.A., Kelley, S.P. and Coffin, M.F., 1995, Timing of hotspot related volcanism and the breakup of Madagascar and India. Science, v. 267, pp. 852-855.

Subrahmanyam, C. and Chand, S., 2006, Evolution of the passive continental margins of India-a geophysical appraisal. Gondwana Research, v. 10, pp. 167-178.

Subrahmanyam, C., Thakur, N.K., Gangadhara Rao, T., Khanna, R., Ramana, M.V. and Subrahmanyam, V., 1999, Tectonics of the Bay of Bengal: new insights from satellite-gravity and ship-borne geophysical data. Earth and Planetary Science Letters, v. 171, pp. 237-251.

Subrahmanyam, V., Rao, D.G., Ramana, M.V., Krishna, K.S., Murty, G.P.S. and Rao, M.G., 1995, Structure and tectonics of the southwestern continental margin of India. Tectonophysics, v. 249, pp. 267-282.

Subrahmanyam, V., Subrahmanyam, A.S., Murty, G.P.S. and Murthy, K.S.R., 2008, Morphology and tectonics of Mahanadi Basin, northeastern continental margin of India from geophysical studies. Marine Geology, v. 253, pp. 63-72.

Talwani, M., Desa, M.A., Ismaiel, M. and Krishna, K.S., 2016, The Tectonic origin of the Bay of Bengal and Bangladesh. Journal of Geophysical Research: Solid Earth, v. 121, pp. 4836-4851.

Talwani, M. and Reif, C., 1998, Laxmi Ridge- a continental sliver in the Arabian Sea. Marine Geophysical Researches, v. 20, pp. 259271.

Todal, A. and Eldholm, O., 1998, Continental margin off western India and Deccan Large Igneous Province. Marine Geophysical Researches, v. 20, pp. 273-291. 
Torsvik, T.H., Amundsen, H., Hartz, E.H., Corfu, F., Kusznir, N., Gaina, C., Doubrovine, P.V., Steinberger, B., Ashwal, L.D. and Jamtveit, B., 2013, A Precambrian microcontinent in the Indian Ocean. Nature Geoscience, v. 6, pp. 223-227.

Torsvik, T.H., Tucker, R.D., Ashwal, L.D., Carter, L.M., Jamtveit, V., Vidyadharan, K.T. and Venkataramana, P., 2000, Late cretaceous India - Madagascar fit and timing of breakup related magmatism. Terra Nova, v. 12, pp. 220-224.

Twinkle, D., Srinivasa Rao, G., Radhakrishna, M. and Murthy, K.S.R., 2016, Crustal structure and rift tectonics across the Cauvery-Palar basin, Eastern Continental Margin of India based on seismic and potential field modelling. Journal of Earth System Science, v. 125, pp. 329-342.

Uddin, A. and Lundberg, N., 2004, Miocene sedimentation and subsidence during continent-continent collision, Bengal basin, Bangladesh. Sedimentary Geology, v. 164, pp. 131-146.

Unnikrishnan, P., Radhakrishna, M. and Prasad, G.K., 2018, Crustal structure and sedimentation history over the Alleppey platform, southwest continental margin of India: Constraints from multichannel seismic and gravity data. Geoscience Frontiers, v. 9, pp. 549-558.

Valsangkar, A.B., Radhakrishnamurthy, C., Subbarao, K.V., Beckinsale, R.D., 1981, Paleomagnetism and Potassium-Argon age studies of acid igneous rocks from the St. Mary Islands. Geological Society of India, Memoir 3, pp. 265-275.

Wiens, D.A., 1986, Historical seismicity near Chagos: a complex deformation zone in the equatorial Indian Ocean. Earth and Planetary Science Letters, v. 76, pp. 350-360.

Wessel, P. and Smith, W.H.F., 1995, New version of the Generic Mapping Tools released. EOS, Transactions of the American Geophysical Union, v. 76, pp. 329.

Whitmarsh, R.B., 1974, Some aspects of plate tectonics in the Arabian Sea. Initial Reports of the Deep Sea Drilling Project. US Government Printing Office, Washington, pp. 527-535.

Yatheesh, V., 2007, A study of tectonic elements of the western continental margin of India and adjoining ocean basins to understand the early opening of the Arabian Sea. PhD Thesis, Goa University, Goa, 212 p.

Yatheesh, V., Bhattacharya, G.C. and Dyment, J., 2009, Early oceanic opening off Western India-Pakistan margin: the Gop Basin revisited. Earth and Planetary Science Letters, v. 284, pp. 399408.

Yatheesh, V., Bhattacharya, G.C. and Mahender, K., 2006, The terrace like feature in the mid-continental slope region off Trivandrum and a plausible model for India-Madagascar juxtaposition in immediate pre-drift scenario. Gondwana Research, v. 10, pp. 179185.

Yatheesh, V., Dyment, J., Bhattacharya, G.C., Jensen, J., Ramprasad, T., Royer, J.Y., Kamesh Raju, K.A., Patriat, P., Chaubey, A.K., Choi, Y. and Srinivas, K., 2008, Central Indian Ocean plate tectonics between Chrons 34 to 20 (83 to $42 \mathrm{Ma}$ ) revisited. EOS Transactions American Geophysical Union, 89(53), Fall Meeting Supplement, Abstract and Poster.

Yatheesh, V., Dyment, J., Bhattacharya, G.C. and Müller, R.D., 2013a, Deciphering detailed plate kinematics of the Indian Ocean and developing a unified model for east Gondwanaland reconstruction: An Indian-Australian-French initiative. DCS Newsletter, v. 23, pp. 2-9.

Yatheesh, V., Dyment, J., Bhattacharya, G.C., Royer, J.Y., Kamesh Raju, K.A., Ramprasad, T., Chaubey, A.K., Patriat, P., Srinivas, K. and Choi, Y., 2019, Detailed structure and plate reconstructions of the Central Indian Ocean between 83.0 and 42.5 Ma (Chrons 34 and 20). Journal of Geophysical Research: Solid Earth, v. 124, pp. 4305-4322.

Yatheesh, V., John Kurian, P., Bhattacharya, G.C. and Rajan, S., 2013b, Morphotectonic architecture of an India-Madagascar breakup related anomalous submarine terrace complex on the southwest continental margin of India. Marine and Petroleum Geology, v. 46, pp. 304-318.

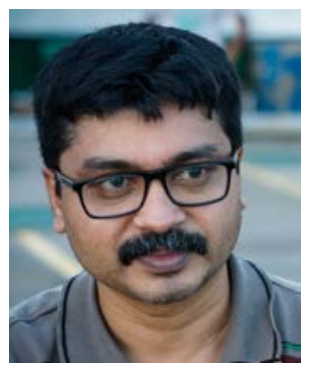

V. Yatheesh obtained his Master of Science (Technology) Degree in Marine Geophysics from Cochin University of Science and Technology, Kerala, India; and PhD Degree in Earth Science from Goa University, India. For the last 20 years, he is pursuing marine geophysical investigations in different sectors of the Indian Ocean, focusing on detailed understanding of crustal architecture and plate tectonic evolution of the continental margins of India and the adjoining deepocean basins, Andaman-Nicobar Subduction Zone and the slowspreading mid-oceanic ridges. 